\title{
The monoamine oxidase inhibition properties of C6- and N1-substituted 3-methyl-3,4-dihydroquinazolin-2(1H)-one derivatives
}

\author{
Lereze Marais $^{1} \mathbb{D} \cdot$ Anél Petzer $^{1,2} \cdot$ Jacobus P. Petzer $^{1,2} \cdot$ Lesetja J. Legoabe $^{1}$
}

Received: 22 March 2019 / Accepted: 15 May 2019 / Published online: 21 May 2019

(c) Springer Nature Switzerland AG 2019

\begin{abstract}
Quinazolinone compounds are of interest in medicinal chemistry since they display a wide range of biological properties. In the present study, a series of C6- and N1-substituted 3-methyl-3,4-dihydroquinazolin-2(1H)-one derivatives were synthesised and evaluated as inhibitors of recombinant human monoamine oxidase (MAO). Some of these quinazolinones are structurally related to a series of 3,4-dihydro-2 $(1 H)$-quinolinone derivatives, which have previously been reported to act as specific inhibitors of MAO-B. The results document that, among 37 compounds synthesised, seven displayed $\mathrm{IC}_{50}$ values $<1 \mu \mathrm{M}$ for the inhibition of MAO-B. The most potent MAO-A inhibitor exhibits an $\mathrm{IC}_{50}$ value of $7.43 \mu \mathrm{M}$ while the most potent MAO-B inhibitor possesses an $\mathrm{IC}_{50}$ value of $0.269 \mu \mathrm{M}$. Good-potency MAO inhibition was only observed among C6-substituted 3-methyl-3,4-dihydroquinazolin-2 $(1 H)$-one derivatives with N1-substitution yielding comparatively lowpotency inhibition. MAO-B-specific inhibitors such as some of the quinazolinone compounds investigated here may act as leads for the design of therapies for neurodegenerative disorders such as Parkinson's disease.
\end{abstract}

\section{Graphical abstract}

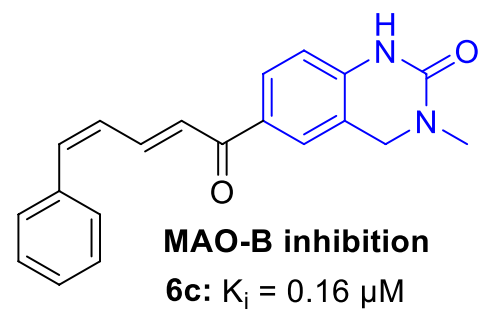

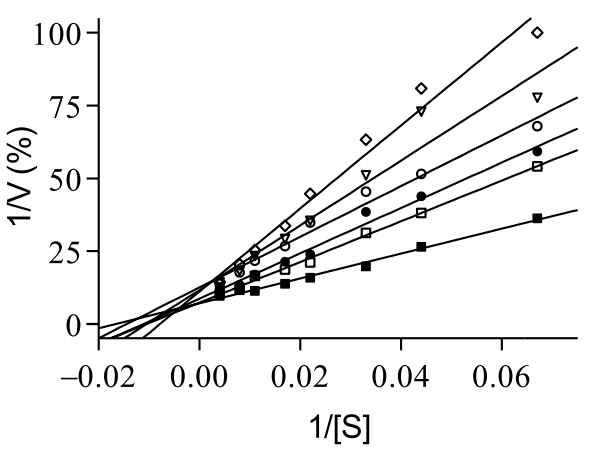

Keywords Monoamine oxidase $\cdot \mathrm{MAO} \cdot$ Inhibition $\cdot$ Reversible $\cdot$ Quinazolinone $\cdot$ Neurodegenerative disorders

\section{Introduction}

Electronic supplementary material The online version of this article (https://doi.org/10.1007/s11030-019-09960-5) contains supplementary material, which is available to authorized users.

Lesetja J. Legoabe

lesetja.legoabe@nwu.ac.za

Extended author information available on the last page of the article
The monoamine oxidase (MAO) enzymes are flavin adenine dinucleotide (FAD)-containing enzymes that catalyse the oxidation of neurotransmitter and dietary amines in both the peripheral and central tissues [1]. Two isoforms of MAO are expressed, MAO-A and MAO-B, which are products of distinct genes [2]. Although MAO-A and MAO-B share a high degree of sequence and structural similarity, 
<smiles>NCCc1c[nH]c2ccc(O)cc12</smiles>

Serotonin<smiles>NCc1ccccc1</smiles>

Benzylamine<smiles>NCCc1ccccc1</smiles>

2-Phenylethylamine<smiles>NCCc1ccc(O)c(O)c1</smiles>

Dopamine<smiles>CNC[C@H](O)c1ccc(O)c(O)c1</smiles>

Epinephrine<smiles>NCCc1ccc(O)cc1</smiles>

Tyramine<smiles>NC[C@@H](O)c1ccc(O)c(O)c1</smiles>

Norepinephrine<smiles>N[C@@H]1C[C@H]1c1ccccc1</smiles>

Tranylcypromine<smiles>C#CCN(C)CCCOc1ccc(Cl)cc1Cl</smiles><smiles>C#CCN(C)[C@@H](C)Cc1ccccc1</smiles>

(R)-Deprenyl<smiles>C#CCNC1CCc2ccccc21</smiles>

Rasagiline<smiles>O=C(NCCN1CCOCC1)c1ccc(Cl)cc1</smiles>

Moclobemide<smiles></smiles>

Fig. 1 Structures of selected MAO substrates and inhibitors

they exhibit different substrate and inhibitor specificities $[1,3,4]$. MAO-A metabolises serotonin and is specifically inhibited by the propargylamine compound clorgyline, while MAO-B metabolises the arylalkylamines, benzylamine and 2-phenethylamine and is specifically inhibited by $(R)$ deprenyl (Fig. 1). Certain substrates such as dopamine, epinephrine, tyramine and norepinephrine are oxidised by both MAO isoforms, while a number of inhibitors (e.g. tranylcypromine) also do not display isoform specificity [1].

Because of their involvement in the catabolism of neurotransmitter amines, MAO-A and MAO-B are considered targets for the treatment of neurological disorders $[1,5]$. In this respect, MAO-A inhibitors are used in the treatment of depression and anxiety, while MAO-B inhibitors are often combined with L-dopa in the treatment of Parkinson's disease $[1,6]$. In Parkinson's disease, MAO-B inhibitors block the MAO-B-catalysed metabolism of dopamine in the brain and thus enhance dopaminergic neurotransmission. In combination with L-dopa, MAO-B inhibitors may enhance dopamine levels derived from the conversion of L-dopa to dopamine and may thus allow for a reduction in the dose of L-dopa required for a therapeutic effect [7, 8]. MAO-B inhibitors may also protect against neuronal injury and neurodegeneration in Parkinson's disease by reducing oxidative damage mediated by hydrogen peroxide, a by-product of MAO catalysis [5]. Currently, two irreversible acting propargylamine compounds, $(R)$-deprenyl and rasagiline, are clinically used for the management of Parkinson's disease, while a reversible inhibitor, safinamide, has recently been approved [1,9]. MAO-A inhibitors that are used in the clinic for the treatment of depression include tranylcypromine, phenelzine, moclobemide, toloxatone and brofaromine [1]. It should be cautioned that reversibility of MAO-A inhibition is an important consideration since irreversible inhibitors such as tranylcypromine and phenelzine may cause a severe hypertensive crisis when combined with food that contains the sympathomimetic amine, tyramine $[10,11]$. With the irreversible inhibition of MAO-A in the gastrointestinal tract and vascular endothelium, dietary tyramine gains access to the circulatory system which leads to the release of norepinephrine from the sympathetic neurons and subsequently a hypertensive reaction [5, 12]. In some instances, this hypertensive reaction can be fatal. This led to the development of reversible MAO-A inhibitors such as moclobemide and brofaromine, which possess a lower liability for increases in blood pressure [13, 14]. MAO-B-specific inhibitors also do not cause tyramine-induced hypertension since MAO-B is absent from the gut tissues [5]. 
<smiles>COC(=O)CN1C(=O)c2ccccc2NC1c1ccc(Cl)cc1</smiles><smiles>COC(=O)C(C)N1C(=O)c2ccccc2NC1c1ccc2c(c1)OCO2</smiles><smiles>NNC(=O)CN1C(=O)c2ccccc2NC1c1ccc2c(c1)OCO2</smiles><smiles>O=C1CCc2cc(OCc3cccc(Br)c3)ccc2N1</smiles>

Fig. 2 Structures of 4(3H)-quinazolinone (1-3) and 3,4-dihydro2(1H)-quinolinone $(\mathbf{4})$ derivatives

Because of their biochemical and clinical significance, the discovery and development of MAO inhibitors are being actively pursued [15]. Quinazolinone is a heterocyclic nitrogen containing system composed of fused phenyl and pyrimidinone (pyrimidone) rings. Over the years, natural and synthetic quinazolinones have attracted attention since they display a variety of biological activities [16-19] including MAO inhibition [20-24]. Other biological activities of quinazolinones include antimicrobial, anticonvulsant, anticancer, antimalarial, antihypertensive, anti-inflammatory, antidiabetic, antitumor, anticholinesterase, dihydrofolate reductase inhibition, as well as the inhibition of cellular phosphorylation and kinases [25]. As mentioned, the MAO inhibitory properties of quinazolinone derivatives have also been reported [20-22]. For example, Khattab and co-workers synthesised a series of $4(3 H)$-quinazolinone derivatives and evaluated them as potential inhibitors of MAO-A and MAO-B. Compounds $1\left(\mathrm{IC}_{50}=3.6 \mathrm{nM}\right), 2\left(\mathrm{IC}_{50}=2.8 \mathrm{nM}\right)$ and $3\left(\mathrm{IC}_{50}=2.1 \mathrm{nM}\right)$ were found to be most active inhibitors and displayed MAO-A inhibition that was comparable to the reference inhibitor, clorgyline (Fig. 2) [22]. Quinazolinones that have been studied as MAO inhibitors are from the $4(3 H)$-quinazolinone class of compounds, while 2(1H)-quinazolinones have not yet been investigated. Based on promising properties of $4(3 H)$-quinazolinones, we envisage that isomeric $2(1 H)$-quinazolinone derivatives may also act as MAO inhibitors. In support of this, structurally related compounds such as 3,4-dihydro-2(1H)-quinolinone derivatives are known to potently and specifically inhibit MAO-B. For example, among a series of 3,4-dihydro2(1H)-quinolinone derivatives substituted on the $\mathrm{C} 6$ and $\mathrm{C} 7$ positions, the most active compound (4) exhibits an $\mathrm{IC}_{50}$ value of $0.086 \mu \mathrm{M}[26,27]$. Based on these findings, the present study synthesises series of C6- and N1-substituted
3-methyl-3,4-dihydroquinazolin-2(1H)-one derivatives. In total, 26 derivatives with C6-substitution $(\mathbf{5 a}-\mathbf{m} ; \mathbf{6 a - m})$ and 11 derivatives with N1-substitution $(\mathbf{7 a}-\mathbf{e} ; \mathbf{8 a}-\mathbf{f})$ were synthesised. The present study is the first investigation of the MAO inhibition properties of 3-methyl-3,4-dihydroquinazolin-2(1H)-one derivatives.

\section{Results and discussion}

\section{Chemistry}

In the current study, two series of 3-methyl-3,4-dihydroquinazolin-2(1H)-ones were synthesised. The first series consists of C6-substituted 3-methyl-3,4-dihydroquinazolin-2(1H)-one derivatives $\mathbf{5} \mathbf{a}-\mathbf{m}$ and $\mathbf{6 a}-\mathbf{m}$ for which benzoyl/acyl and cinnamoyl C6-substitutions were considered, respectively. The C6-substituted benzoyl/acyl derivatives (5) were synthesised by Friedel-Crafts acylation (Fig. 3). To a solution of aluminium trichloride and 3-methyl-3,4-dihydroquinazolin-2(1H)-one in carbon disulphide, the appropriate acyl chloride or bromide was added. The reaction mixture was heated under reflux $\left(50{ }^{\circ} \mathrm{C}\right)$ for $24 \mathrm{~h}$, and on completion, the reaction was terminated by the addition of a mixture of ice and water. The product was collected by filtration, dried in a convection oven and recrystallised from ethanol. Attempts to synthesise the C6-substituted cinnamoyl derivatives by direct acylation failed, and with the exception of $\mathbf{6 b}$, the target cinnamoyl derivatives $\mathbf{6}$ were thus synthesised from 6-acetyl-3-methyl-3,4-dihydroquinazolin-2(1H)-one (5l). Derivative $\mathbf{6 b}$ was synthesised by employing $\mathbf{5 m}$ as starting material. To a solution of $\mathbf{5 1}$ or $\mathbf{5 m}$ in a mixture of hydrochloric acid $(32 \%)$ and methanol, an appropriate benzaldehyde (or cinnamaldehyde for $\mathbf{6 c}$ ) was added. The reaction was heated under reflux for 24-48 h, and on completion, the product was isolated and recrystallised as described above.

The target 3-methyl-3,4-dihydroquinazolin-2(1H)-one derivatives 5 and 6 were obtained in yields of 13-100\%. The structures were determined by ${ }^{1} \mathrm{H}$ NMR, ${ }^{13} \mathrm{C}$ NMR and mass spectrometry, while purities were estimated by HPLC as cited in Experimental section. The successful synthesis of the cinnamoyl derivatives 6 was verified by the presence of the ${ }^{1} \mathrm{H}$ NMR signals of the vinylic protons of the substituent.

The second series, the N1-substituted 3-methyl3,4-dihydroquinazolin-2(1H)-one derivatives $\mathbf{7 a - e}$ and $\mathbf{8 a}-\mathbf{f}$, was synthesised according to the pathway shown in Fig. 4. 3,4-Dihydro-3-methyl-2(1H)-quinazolinone was dissolved in N,N-dimethylformamide (DMF) and treated with sodium hydride at $0{ }^{\circ} \mathrm{C}$. The reaction was stirred for $20 \mathrm{~min}$, and an appropriate alkyl bromide or alkyl chloride was subsequently added. The reaction was stirred for a further $1 \mathrm{~h}$ at $0{ }^{\circ} \mathrm{C}$, and after completion was partitioned 

tuted 3-methyl-3,4-dihydroquinazolin-2 $(1 H)$-one derivatives 5 and 6. Key a $\mathrm{AlCl}_{3}$, $\mathrm{CS}_{2}$, reflux, $24 \mathrm{~h}$; b $\mathrm{HCl}(32 \%) /$ methanol, reflux, 24-48 h
Fig. 3 Synthesis of C6-substi-

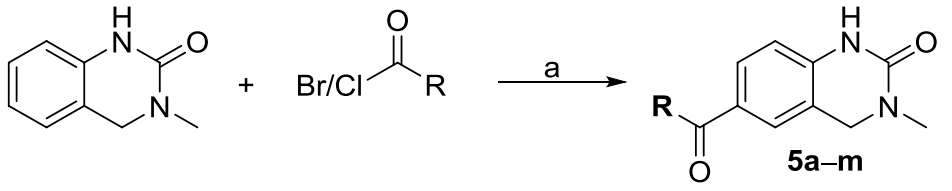<smiles>[Y][X]c1cccc(C=CC=CC(=O)c2ccc3c(c2)CN(C)C(=O)N3)c1</smiles><smiles>CCC(=O)c1ccc2c(c1)CN(C)C(=O)N2</smiles><smiles>CC(=O)c1ccc2c(c1)CN(C)C(=O)N2</smiles>

Fig. 4 Synthesis of N1-substituted 3-methyl-3,4-dihydroquinazolin-2 $(1 H)$-one derivatives 7 and $\mathbf{8}$. Key a NaH, DMF, $0{ }^{\circ} \mathrm{C}$

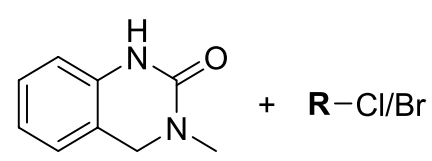<smiles>C[CH]C</smiles><smiles>[R]N1C(=O)N(C)Cc2ccccc21</smiles><smiles>[R]n1c(=O)n(C)c(=O)c2ccccc21</smiles>

between water and ethyl acetate. The organic phase was dried over $\mathrm{MgSO}_{4}$ and then concentrated in vacuo, and the resulting residue was recrystallised from ethanol, ethyl acetate or a mixture of petroleum ether and ethyl acetate/ethanol. Compounds $7 \mathbf{b}, \mathbf{7 c}, \mathbf{7 e}, \mathbf{8 a}$ and $\mathbf{8 c}$ were purified by column chromatography. The 3-methyl-3,4-dihydroquinazolin-2(1H)-one derivatives were obtained in yields of $10-67 \%$. The structures were verified, as cited in Experimental section, by ${ }^{1} \mathrm{H} \mathrm{NMR},{ }^{13} \mathrm{C}$ NMR and mass spectrometry, and purity was estimated by HPLC. Interestingly, this procedure yielded both the 3-methyl3,4-dihydroquinazolin-2(1H)-one derivatives $\mathbf{7 a - e}$ and the 3-methyl-3,4-dihydroquinazolin-2(1H,3H)-diones, compounds 8a-f. For $7 \mathbf{a}-\mathbf{e},{ }^{1} \mathrm{H}$ NMR spectra exhibit a singlet $(2 \mathrm{H})$ at approximately $4.5 \mathrm{ppm}$ for the methylene protons at position 4 , which was absent for compound $\mathbf{8 a}-\mathbf{f}$. Furthermore, in the ${ }^{13} \mathrm{C}$ NMR spectra of $\mathbf{8 a}-\mathbf{f}$, an additional carbonyl carbon signal at approximately 162 ppm was observed.

\section{$I_{50}$ values for the inhibition of MAO}

The $\mathrm{IC}_{50}$ values for the inhibition of MAO-A and MAO-B were determined by employing the human recombinant enzymes [28, 29]. Kynuramine, a nonspecific MAO substrate, was used to measure the catalytic rates of both enzyme isoforms. Kynuramine is non-fluorescent, and after MAO-catalysed oxidative deamination yields 4-hydroxyquinoline, a metabolite which fluoresces in alkaline media. The rate of kynuramine oxidation was thus determined by measuring the production of 4-hydroxyquinoline by fluorescence spectrophotometry $\left(\lambda_{\mathrm{ex}}=310, \lambda_{\mathrm{em}}=400\right)$ at the endpoint of the enzyme reaction. The enzyme reactions contained substrate $(50 \mu \mathrm{M})$ and test inhibitor $(0.003-100 \mu \mathrm{M})$ in potassium phosphate buffer $(\mathrm{pH} 7.4,100 \mu \mathrm{M})$. After the reactions were initiated with the addition of the enzyme, the reactions were incubated for $20 \mathrm{~min}$ at $37^{\circ} \mathrm{C}$ and terminated with the addition of sodium hydroxide $(2 \mathrm{~N})$. Control reactions were conducted in the absence of inhibitor. $\mathrm{IC}_{50}$ values were estimated by constructing sigmoidal plots of enzyme catalytic rate versus the logarithm of inhibitor concentration. Examples of such plots are shown in Fig. 5. 


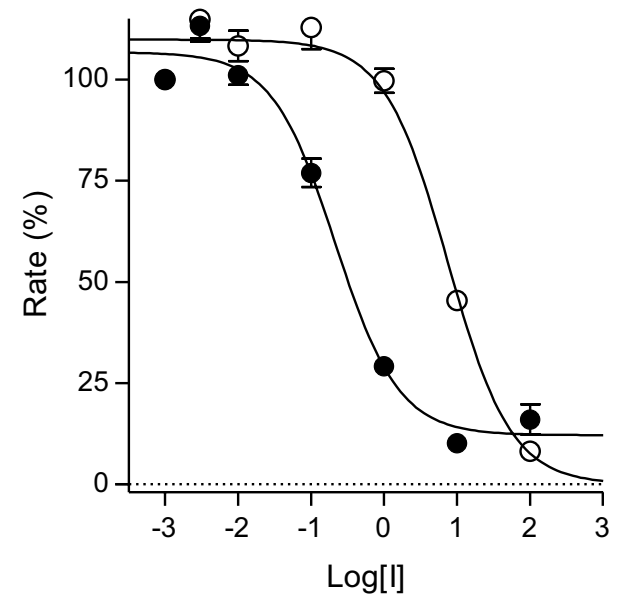

Fig. 5 Sigmoidal plots for the inhibition of MAO-A and MAO-B by $\mathbf{6 b}$ (open circles) and $\mathbf{6 c}$ (filled circles), respectively
The $\mathrm{IC}_{50}$ values for the inhibition of the human MAOs by 3-methyl-3,4-dihydroquinazolin-2(1H)-one derivatives are given in Tables 1, 2, 3 and 4. From the results, it is evident that the 3-methyl-3,4-dihydroquinazolin-2(1H)-one derivatives 5-8 are weak MAO-A inhibitors with $\mathrm{IC}_{50}>7.43 \mu \mathrm{M}$. Only three compounds (e.g. $\mathbf{6 b}, \mathbf{6 g}$ and $\mathbf{6 h}$ ) possess $\mathrm{IC}_{50}<15 \mu \mathrm{M}$ for the inhibition of MAO-A. Furthermore, with the exception of $\mathbf{5 c}, \mathbf{5 j}$ and $\mathbf{7 a}-\mathbf{d}$, none of the compounds evaluated are specific for the MAO-A isoform. These compounds are, however, very weak inhibitors of MAO-A. While no clear trend exists for the inhibition of MAO-A, it is noteworthy that none of the 3-methyl-3,4-dihydroquinazolin-2(1H,3H)-diones (8a-f) exhibited inhibition, even at a maximal tested concentration of $100 \mu \mathrm{M}$. Furthermore, the three most potent MAO-A inhibitors, $\mathbf{6 b}, \mathbf{6} \mathbf{g}$ and $\mathbf{6 h}$, are all cinnamoyl-substituted 3-methyl-3,4-dihydroquinazolin$2(1 H)$-one derivatives.
Table $1 \mathrm{IC}_{50}$ values for the inhibition of recombinant human MAO-A and MAO-B by 3-methyl-3,4dihydroquinazolin-2(1H)-one derivatives 5<smiles>[R]C(=O)c1ccc2c(c1)CN(C)C(=O)N2</smiles>

\begin{tabular}{|c|c|c|c|c|}
\hline & \multirow[b]{2}{*}{$\mathbf{R}$} & \multicolumn{2}{|l|}{$\mathrm{IC}_{50}(\mu \mathrm{M})^{\mathrm{a}}$} & \multirow[b]{2}{*}{$\mathbf{S I}^{\mathbf{b}}$} \\
\hline & & MAO A & MAO B & \\
\hline $5 \mathbf{a}$ & $\mathbb{v}$ & $51.7 \pm 3.70$ & $30.8 \pm 0.638$ & 1.7 \\
\hline $5 b$ & & $50.9 \pm 14.3$ & $36.8 \pm 1.334$ & 1.4 \\
\hline $5 c$ & & $86.7 \pm 4.62$ & No inh ${ }^{c}$ & - \\
\hline $5 d$ & & $24.3 \pm 2.84$ & $2.22 \pm 0.409$ & 10.9 \\
\hline $5 e$ & & $54.9 \pm 27.2$ & $27.2 \pm 3.104$ & 2.0 \\
\hline $5 f$ & & $71.6 \pm 12.1$ & $20.4 \pm 1.410$ & 3.5 \\
\hline $5 \mathrm{~g}$ & & $50.0 \pm 4.774$ & $9.66 \pm 0.897$ & 5.2 \\
\hline $5 \mathbf{h}$ & & No $\mathrm{inh}^{\mathrm{c}}$ & No inh ${ }^{c}$ & - \\
\hline $5 i$ & & No $\operatorname{inh}^{c}$ & No inh ${ }^{c}$ & - \\
\hline $5 j$ & & $86.2 \pm 16.2$ & No inh ${ }^{c}$ & - \\
\hline $5 \mathbf{k}$ & & No $\mathrm{inh}^{\mathrm{c}}$ & No inh ${ }^{c}$ & - \\
\hline 51 & $\mathrm{CH}_{3}$ & No inh ${ }^{c}$ & No inh ${ }^{c}$ & - \\
\hline $5 \mathrm{~m}$ & $\mathrm{CH}_{3} \mathrm{CH}_{2}$ & No inh ${ }^{c}$ & No inh ${ }^{c}$ & - \\
\hline Tolc & & $3.92^{\mathrm{d}}$ & - & - \\
\hline Laz: & & - & $0.091^{\mathrm{d}}$ & - \\
\hline
\end{tabular}

${ }^{\mathrm{a}}$ All values are expressed as the mean \pm standard deviation $(\mathrm{SD})$ of triplicate determinations

${ }^{\mathrm{b}}$ Selectivity index $(\mathrm{SI})=\mathrm{IC}_{50}(\mathrm{MAO}-\mathrm{A}) / \mathrm{IC}_{50}(\mathrm{MAO}-\mathrm{B})$

${ }^{\mathrm{c}}$ No inhibition observed at a maximal tested concentration of $100 \mu \mathrm{M}$

${ }^{\mathrm{d}}$ Value obtained from literature [34] 
Table $2 \mathrm{IC}_{50}$ values for the inhibition of recombinant human MAO-A and MAO-B by 3-methyl-3,4-dihydroquinazolin-2(1H)-one derivatives 6<smiles>[H][Z6]1ccccc1C=CC(=O)c1ccc2c(c1)CN(C)C(=O)N2</smiles><smiles>C/C(=C/c1ccccc1)C(=O)c1ccc2c(c1)CN(C)C(=O)N2</smiles><smiles>CN1Cc2cc(C(=O)/C=C/C=C\c3ccccc3)ccc2NC1=O</smiles>

\begin{tabular}{|c|c|c|c|c|}
\hline & \multirow[t]{2}{*}{$\mathrm{X}$} & \multicolumn{2}{|l|}{$\mathrm{IC}_{50}(\mu \mathrm{M})^{\mathrm{a}}$} & \multirow[t]{2}{*}{$\mathrm{SI}^{\mathrm{b}}$} \\
\hline & & MAO A & MAO B & \\
\hline $6 \mathbf{a}$ & $\mathrm{H}$ & No inh ${ }^{c}$ & $1.06 \pm 0.066$ & - \\
\hline $\mathbf{6 b}$ & - & $7.43 \pm 0.178$ & $2.54 \pm 0.103$ & 2.9 \\
\hline $6 c$ & - & $24.7 \pm 2.36$ & $0.269 \pm 0.071$ & 91.8 \\
\hline 6d & $4-\mathrm{OCH}_{3}$ & No inh ${ }^{c}$ & $3.72 \pm 0.044$ & - \\
\hline $6 e$ & $4-\mathrm{OH}$ & $24.6 \pm 3.80$ & $3.16 \pm 0.460$ & 7.8 \\
\hline $6 f$ & $4-\mathrm{Cl}$ & $78.1 \pm 9.16$ & $0.607 \pm 0.034$ & 128.7 \\
\hline $6 \mathrm{~g}$ & $4-\mathrm{CN}$ & $8.86 \pm 0.532$ & $1.23 \pm 0.289$ & 7.2 \\
\hline $6 h$ & $4-\mathrm{CF}_{3}$ & $11.1 \pm 1.63$ & $0.406 \pm 0.024$ & 27.3 \\
\hline $\mathbf{6 i}$ & $3-\mathrm{Cl}$ & $44.2 \pm 7.10$ & $0.350 \pm 0.030$ & 126.3 \\
\hline $\mathbf{6 j}$ & $2-\mathrm{Cl}$ & $52.6 \pm 2.93$ & $0.416 \pm 0.029$ & 126.4 \\
\hline 6k & $4-\mathrm{F}$ & No inh ${ }^{c}$ & $0.446 \pm 0.082$ & - \\
\hline 61 & $4-\mathrm{Br}$ & $21.8 \pm 0.566$ & $1.01 \pm 0.101$ & 21.6 \\
\hline $6 m$ & $3-\mathrm{F}$ & No inh ${ }^{c}$ & $0.513 \pm 0.031$ & - \\
\hline
\end{tabular}

See Table 1 for footnotes

Table $3 \mathrm{IC}_{50}$ values for the inhibition of recombinant human MAO-A and MAO-B by 3-methyl-3,4-dihydroquinazolin-2(1H)-one derivatives 7<smiles>[X]c1ccc(CN2C(=O)N(C)Cc3ccccc32)cc1</smiles>

\begin{tabular}{|c|c|c|c|c|}
\hline \multirow[t]{2}{*}{$\bar{X}$} & \multirow[t]{2}{*}{$\mathrm{X}$} & \multicolumn{2}{|l|}{$\mathrm{IC}_{50}(\mu \mathrm{M})^{\mathrm{a}}$} & \multirow[t]{2}{*}{$\mathrm{SI}^{\mathrm{b}}$} \\
\hline & & MAO A & MAO B & \\
\hline $7 a$ & $4-\mathrm{Cl}$ & $86.7 \pm 4.97$ & No $\operatorname{inh}^{\mathrm{c}}$ & - \\
\hline $7 b$ & $3-\mathrm{Br}$ & $50.2 \pm 7.22$ & No inh ${ }^{c}$ & - \\
\hline 7c & $4-\mathrm{Br}$ & $47.9 \pm 3.17$ & No inh ${ }^{c}$ & - \\
\hline 7d & 4-I & $55.8 \pm 5.12$ & No inh ${ }^{c}$ & - \\
\hline $7 e$ & $4-\mathrm{CF}_{3}$ & No inh ${ }^{c}$ & No inh ${ }^{c}$ & - \\
\hline
\end{tabular}

See Table 1 for footnotes
In general, the 3-methyl-3,4-dihydroquinazolin-2(1H)one derivatives are more potent MAO-B inhibitors. Among the 37 compounds synthesised, seven displayed $\mathrm{IC}_{50}<1 \mu \mathrm{M}$ for the inhibition of MAO-B. The most potent MAO-B inhibitor $(\mathbf{6 c})$ possesses an $\mathrm{IC}_{50}$ value of $0.269 \mu \mathrm{M}$. Good-potency MAO inhibition was only observed among C6-substituted 3-methyl-3,4-dihydroquinazolin-2(1H)-one derivatives, specifically among the cinnamoyl-substituted compounds 6, which all display $\mathrm{IC}_{50}$ values $<3.72 \mu \mathrm{M}$. Among the benzoyl/acyl-substituted derivatives $\mathbf{5}$, only two compounds (5d and $\mathbf{5 g}$ ) possess $\mathrm{IC}_{50}<10 \mu \mathrm{M}$ of the inhibition of MAO-B. With N1-substitution, no MAO-B inhibition was observed, even at a maximal tested concentration of $100 \mu \mathrm{M}$.

The following structure-activity relationships (SARs) for MAO inhibition were observed. Substitution with chlorine in the para and fluorine in meta positions of the benzoyl moiety led to more potent MAO-B inhibitors (5d and 5g) among the 3-methyl-3,4-dihydroquinazolin-2(1H)-one derivatives 5 . The position of substituent is important since the para (5e) and ortho (5f) fluorine-substituted derivatives are lower potency MAO-B inhibitors. Replacement of the benzoyl phenyl ring (5a) with the cyclohexyl (5c) led to the loss of MAO-B inhibition activity, suggesting that the aromatic ring is essential for activity. This is supported by 
Table $4 \mathrm{IC}_{50}$ values for the inhibition of recombinant human MAO-A and MAO-B by 3-methyl-3,4 dihydroquinazolin-2,4(1H,3H)diones derivatives $\mathbf{8}$<smiles>[R]n1c(=O)n(C)c(=O)c2ccccc21</smiles>

\begin{tabular}{|c|c|c|c|c|}
\hline & \multirow[b]{2}{*}{$\mathbf{R}$} & \multicolumn{2}{|c|}{$\mathrm{IC}_{50}(\mu \mathrm{M})^{\mathrm{a}}$} & \multirow[b]{2}{*}{$\mathbf{S I}^{\mathbf{b}}$} \\
\hline & & MAO A & МАО В & \\
\hline $8 a$ & & No $\operatorname{inh}^{c}$ & No inh ${ }^{c}$ & - \\
\hline $8 b$ & & No $i n h^{c}$ & No inh ${ }^{c}$ & - \\
\hline $8 c$ & & No inh ${ }^{c}$ & No inh ${ }^{c}$ & - \\
\hline 8d & & No inh ${ }^{c}$ & No inh ${ }^{c}$ & - \\
\hline $8 e$ & & No inh ${ }^{c}$ & No inh ${ }^{\mathrm{c}}$ & - \\
\hline $8 f$ & & No inh ${ }^{\mathrm{c}}$ & No inh ${ }^{c}$ & - \\
\hline
\end{tabular}

See Table 1 for footnotes the observation that the compounds bearing non-aromatic alkyl or alkyl halide substituents, $\mathbf{5 i}-\mathbf{m}$, are also devoid of MAO-B inhibition activity. Compounds substituted with heteroaromatic groups, such as furanyl, $(\mathbf{5 h})$, also do not inhibit MAO-B which indicates that heteroaromatic groups are less appropriate than the phenyl. Interestingly, phenyland benzyl-containing compounds $(\mathbf{5 a})\left(\mathrm{IC}_{50}=51.7 \mu \mathrm{M}\right)$ and $\mathbf{5 b}\left(\mathrm{IC}_{50}=50.9 \mu \mathrm{M}\right)$ possess similar MAO-A inhibition potencies, while a reduction and loss of MAO-A inhibition were observed when the phenyl group was replaced with the cyclohexyl (5c) and furanyl (5h) groups, respectively.

In contrast to the benzoyl-substituted derivative 5a $\left(\mathrm{IC}_{50}=30.8 \mu \mathrm{M}\right)$, cinnamoyl substitution to yield $\mathbf{6 a}$ $\left(\mathrm{IC}_{50}=1.06 \mu \mathrm{M}\right)$ resulted in more potent MAO-B inhibition. Compound $\mathbf{6 c}\left(\mathrm{IC}_{50}=0.269 \mu \mathrm{M}\right)$, in turn, is approximately fourfold more potent than compound $\mathbf{6 a}$, which shows that extension of conjugation (by replacing the styryl group with a phenylbutadienyl) further enhances MAO-B inhibition activity. Recently, it has been reported that compounds containing $\alpha, \beta, \gamma, \delta$-diunsaturated ketones, such as cinnamylidene acetophenones, display antioxidant and anti-inflammatory activities [30]. Compound $\mathbf{6 c}$ may thus be a candidate compound that displays multiple biological activities relevant to the treatment of Parkinson's disease including MAO-B inhibition, antioxidant and anti-inflammatory activities. MAO inhibitors with antioxidant and antiinflammatory properties would be beneficial in the treatment of Parkinson's disease, since inflammation and oxidative stress have been linked to the pathogenesis of Parkinson's disease [31]. Substitution with halogens and alkyl groups (e.g. 6f-m) on the cinnamoyl phenyl ring leads to improved
MAO-B inhibition activity compared to substitution with a polar hydroxyl group (e.g. 6e). Compound 6a is devoid MAO-A inhibition activity; however, extension of conjugation (e.g. 6c) results in a compound with MAO-A inhibition, although weak. Substitution on the cinnamoyl phenyl ring of 6a with the para nitrile $(\mathbf{6 g})$ and trifluoromethyl $(\mathbf{6 h})$ groups yields the second and third most potent MAO-A inhibitors of the study. Substitution with a smaller halogen (fluorine) on the cinnamoyl phenyl ring produced compounds which lacked MAO-A inhibition activity $(\mathbf{6 k}$ and $\mathbf{6 m})$, although substitution with bromine and chlorine produced active MAO-A inhibitors (6f, $\mathbf{6 i}, \mathbf{6 j}$ and $\mathbf{6 1})$. Interestingly, compound $\mathbf{6 e}$, the hydroxy-substituted compound, was active as a MAO-A inhibitor $\left(\mathrm{IC}_{50}=24.6 \mu \mathrm{M}\right)$, although the methoxysubstituted homologue (6d) was found to be inactive. For compounds $\mathbf{6}$, in general, the electron-withdrawing halogen substituents yielded more potent MAO-B inhibition compared to electron-releasing substituents $\left(\mathrm{OCH}_{3}\right.$ and $\left.\mathrm{OH}\right)$.

Although the N1-substituted 3-methyl-3,4-dihydroquinazolin-2 $(1 H)$-one derivatives (7a-d) are weak MAO-A inhibitors, they exhibited specificity for the MAO-A isoform. In contrast, the 3-methyl-3,4-dihydroquinazolin-2,4(1H,3H)diones $(\mathbf{8 a}-\mathbf{f})$ were found to be inactive against both MAO isoforms. For the 3-methyl-3,4-dihydroquinazolin2,4(1H,3H)-diones, a number of structural modifications were explored; however, no MAO inhibition was observed. It may thus be concluded that 3-methyl-3,4-dihydroquinazolin-2,4(1H,3H)-diones are not suitable for the design of MAO inhibitors. Among the N-substituted 3-methyl3,4-dihydroquinazolin-2(1H)-one derivatives, substitution with halogens at the appropriate position on the benzyl 
Fig. 6 Reversibility of inhibition of MAO-A and MAO-B by compounds $\mathbf{6 b}$ and $\mathbf{6 c}$, respectively. MAO-A was pre-incubated in the absence of inhibitor and presence of $\mathbf{6 b}$ and pargyline (a), and MAO-B was pre-incubated in the absence of inhibitor and presence of $\mathbf{6 c}$ and $(R)$-deprenyl (b). After dialysis, the residual enzyme activities were measured. For comparison, the activities of undialysed mixtures of the MAOs and the test inhibitors were also measured (a)

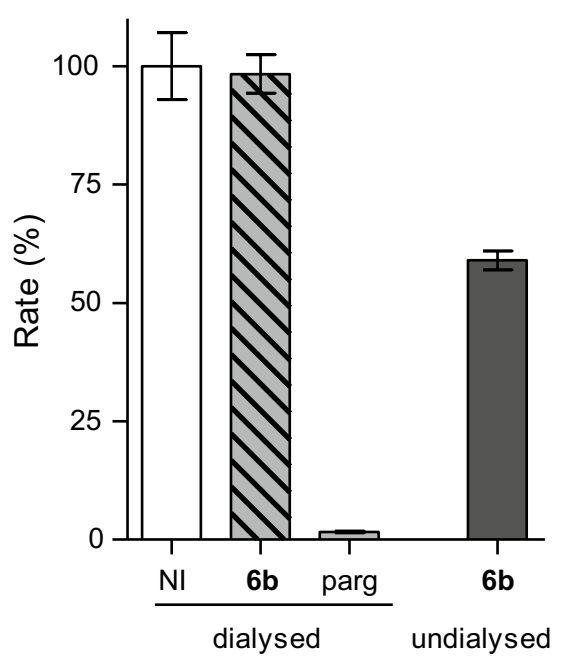

(b)

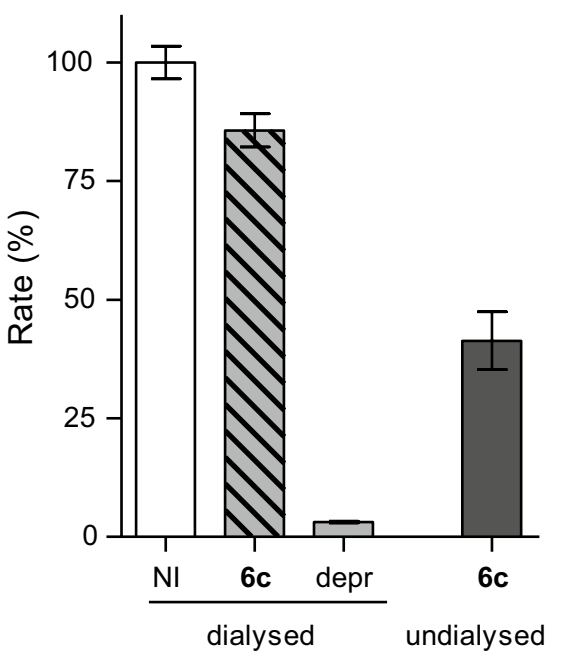

moiety produced compounds with MAO-A inhibition activity (7a-d), with compound 7c displaying the highest inhibition potency $\left(\mathrm{IC}_{50}=47.9 \mu \mathrm{M}\right)$. Interestingly, the MAO-A inhibition potencies of the bromine-substituted compounds (7b and 7c) were within experimental error identical, which shows that the position (para versus meta) is not an important consideration.

\section{Reversibility of MAO inhibition}

As mentioned, reversibility of MAO inhibition, especially of the MAO-A isoform, is an important consideration since irreversible MAO-A inhibitors may lead to a potentially fatal hypertensive crisis when combined with certain food [11]. Furthermore, compared to reversible inhibition, irreversible inhibitors also may have the disadvantage of slow and variable rates of enzyme recovery after drug withdrawal [32, 33]. For these reasons, we have set out to investigate the reversibility of MAO inhibition by selecting the 3-methyl3,4-dihydroquinazolin-2(1H)-one derivatives. Compounds $\mathbf{6 b}$ and $\mathbf{6 c}$ were selected to investigate the reversibility of MAO-A and MAO-B inhibition, respectively. Since these compounds do not possess functional groups [e.g. propargylamine, hydrazine, cyclopropylamine, haloallylamine or $\mathrm{N}$-(2-aminoethyl)carboxamide] that are associated with irreversible MAO inhibition, it is expected that $\mathbf{6 b}$ and $\mathbf{6 c}$ would act as reversible inhibitors. Dialysis was used to investigate the reversibility of inhibition. Compounds $\mathbf{6 b}$ and $\mathbf{6 c}$, at concentrations of $4 \times \mathrm{IC}_{50}$, were combined with the MAO enzyme and pre-incubated for $20 \mathrm{~min}$ followed by dialysis for $24 \mathrm{~h}$. Following dialysis, the reactions were diluted twofold with the addition of kynuramine to yield an inhibitor concentration of $2 \times \mathrm{IC}_{50}$. The residual enzyme activities were measured and are presented graphically (Fig. 6). Similar dialysis experiments in the presence of the irreversible inhibitors, pargyline and $(R)$-deprenyl, served as positive controls, while dialysis of the enzymes in the absence of inhibitor served as negative control. For comparison, the MAO activities of undialysed mixtures of the MAOs and the test inhibitors were also measured.

For the negative control (absence of the inhibitor), the residual activity was set to $100 \%$. As shown by the results, 6b and $\mathbf{6 c}$ are reversible MAO inhibitors since dialysis restores MAO-A and MAO-B activity to $98 \%$ and $86 \%$, respectively. Inhibition, however, persists in undialysed mixtures of MAO-A and MAO-B with these test inhibitors, with the residual activity at $59 \%$ and $41 \%$, respectively. Dialysis of the mixtures containing the MAOs and the irreversible inhibitors, pargyline and $(R)$-deprenyl, does not restore activity with the residual activities at $1.6 \%$ and $3.1 \%$, respectively.

\section{Mode of inhibition}

Lineweaver-Burk plots were constructed to investigate the modes of MAO-A and MAO-B inhibition by $\mathbf{6 b}$ and $\mathbf{6 c}$, respectively. MAO activity were measured at eight different kynuramine concentrations $(15-250 \mu \mathrm{M})$, in the absence and presence of five different concentrations of the inhibitors. As shown in Fig. 7, the Lineweaver-Burk plots for the inhibition of both MAO-A and MAO-B are linear and have common y-intercepts. This is typical for competitive inhibition, and from these data, it may be concluded that $\mathbf{6 b}$ and $\mathbf{6 c}$ are competitive inhibitors of the MAO isozymes, respectively. This further supports the finding of the dialysis studies that the inhibition is reversible. From replots of the slopes of the Lineweaver-Burk plots versus inhibitor concentration, $K_{i}$ values of 6.9 and $0.16 \mu \mathrm{M}$ for the inhibition of MAO-A and MAO-B by $\mathbf{6 b}$ and $\mathbf{6 c}$, respectively, are estimated. 

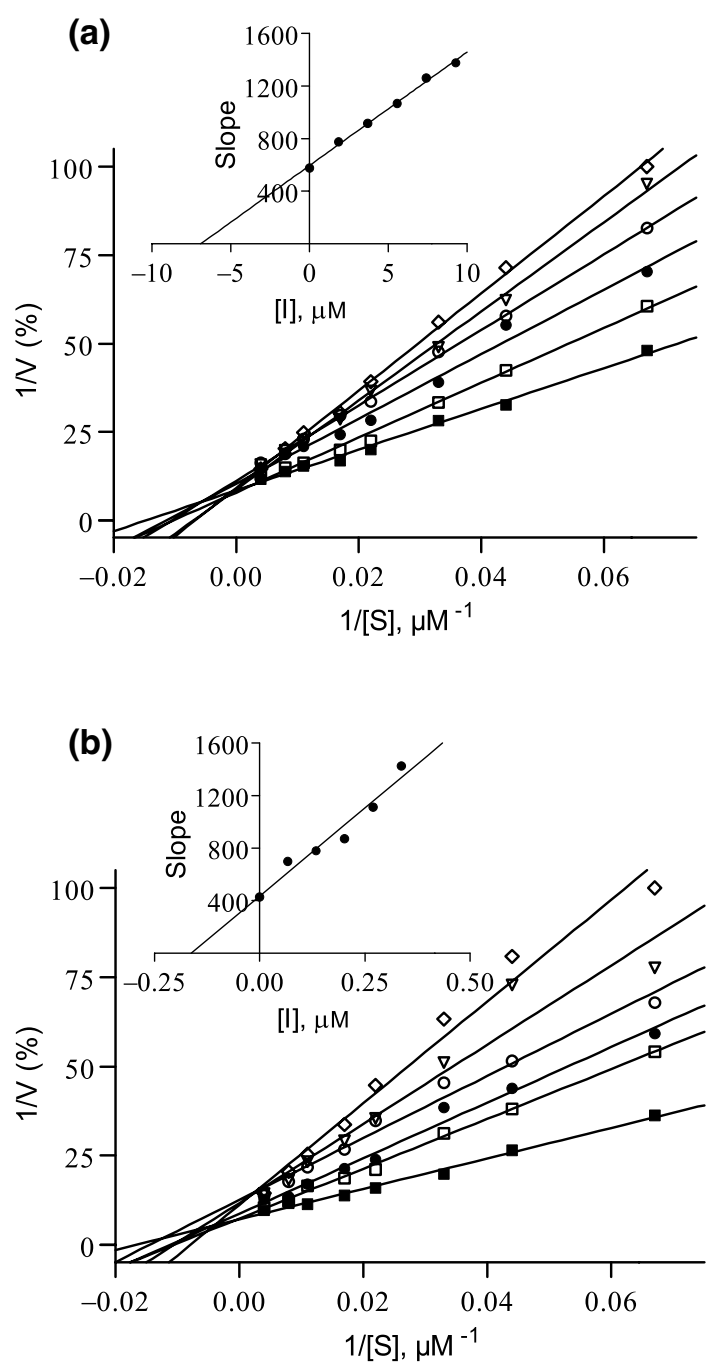

Fig. 7 Lineweaver-Burk plots of human MAO-A and MAO-B catalytic activities in the absence (filled squares) and presence of various concentrations of $\mathbf{6 b}(\mathbf{a})$ and $\mathbf{6 c}(\mathbf{b})$, respectively. For MAO-A, the concentrations of $\mathbf{6 b}$ were $1.86 \mu \mathrm{M}$ (open squares), $3.72 \mu \mathrm{M}$ (filled circles), $5.58 \mu \mathrm{M}$ (open circles), $7.43 \mu \mathrm{M}$ (triangles) and $9.29 \mu \mathrm{M}$ (diamonds). For the studies with MAO-B, the concentrations of $\mathbf{6 c}$ were $0.067 \mu \mathrm{M}$ (open squares), $0.134 \mu \mathrm{M}$ (filed circles), $0.202 \mu \mathrm{M}$ (open circles), $0.269 \mu \mathrm{M}$ (triangles) and $0.336 \mu \mathrm{M}$ (diamonds)

\section{Conclusions}

The present study shows that a number of compounds among a series of C6-substituted 3-methyl-3,4-dihydroquinazolin$2(1 H)$-one derivatives act as reversible and specific MAO-B inhibitors. Such compounds are thus suitable leads for the development of selective MAO-B inhibitors that may find application in neurodegenerative disorders such as Parkinson's disease. The N1-substituted 3-methyl-3,4-dihydroquinazolin-2 $(1 H)$-one derivatives $(7)$ proved to be MAOA-specific inhibitors, although the inhibition potencies were weak. An interesting SAR for MAO-B inhibition by the C6-substituted 3-methyl-3,4-dihydroquinazolin-2(1H)one derivatives is the increase in potency when the conjugation is extended by replacing the cinnamyl group with a cinnamylidene group. In this respect, the cinnamylidene derivative $\mathbf{6 c}$ is the most potent MAO-B inhibitor of the series. Some derivatives also exhibited MAO-A inhibition, with $6 \mathbf{b}$ in particular displaying an $\mathrm{IC}_{50}$ value of $7.43 \mu \mathrm{M}$. This potency is comparable to reference inhibitors such as toloxatone, which is reported to inhibit MAO-A with an $\mathrm{IC}_{50}$ value of $3.92 \mu \mathrm{M}$ [34]. Since dopamine is metabolised by both MAO isoforms, nonspecific MAO inhibitors such as 6b may be considered useful for the therapy of Parkinson's disease. The present study also shows that the 3-methyl3,4-dihydroquinazolin-2(1H)-one class of compounds are reversible inhibitors of both MAO-A and MAO-B. This is significant since reversible MAO inhibitors are less likely to cause tyramine-induced hypertension than irreversible MAO inhibitors. Based on these findings, it may be concluded that C6-substituted 3-methyl-3,4-dihydroquinazolin-2(1H)-one derivatives are promising MAO-B inhibitors for the treatment of Parkinson's disease, while nonspecific MAO inhibitors may also find application in the treatment of depression, which often is a comorbid condition of Parkinson's disease.

\section{Experimental section}

\section{Chemicals and instrumentation}

Unless otherwise specified, all chemicals were obtained from Sigma-Aldrich and were used without further purification. Proton $\left({ }^{1} \mathrm{H}\right)$ and carbon $\left({ }^{13} \mathrm{C}\right)$ NMR spectra were recorded in deuterated dimethyl sulfoxide (DMSO- $d 6$ ) or deuterochloroform $\left(\mathrm{CDCl}_{3}\right)$ with a Bruker Avance III 600 spectrometer at frequencies of $600 \mathrm{MHz}$ and $151 \mathrm{MHz}$, respectively. MestReNova was used to process and analyse NMR data. ${ }^{1} \mathrm{H}$ NMR data are reported by providing the chemical shift $(\delta)$, the integration and multiplicity of the signals. The chemical shifts $(\delta)$ are given in parts per million (ppm) and the coupling constants $(J)$ in $\mathrm{Hz}$. Spin multiplicities are given as singlet (s), doublet (d), doublet of doublets (dd), doublet of doublet of doublets (ddd), triplet (t), triplet of doublet (td) and multiplet (m). High-resolution mass spectra (HRMS) were recorded on a Bruker micrOTOF-QII mass spectrometer in atmospheric-pressure chemical ionisation (APCI) mode. Melting points (mp) were determined with a Buchi B-545 melting point apparatus and are uncorrected. Thin-layer chromatography (TLC) was carried out to monitor the progress of reactions. Silica gel 60 (Merck) $F_{254}$ sheets were used for TLC, and the developed sheets were visualised under a UV254 light or by staining with iodine vapour. A Varian Cary Eclipse instrument was employed for fluorescence spectrophotometry. For the enzymology, 
microsomes from insect cells containing recombinant human MAO-A and MAO-B (5 mg protein/mL) and kynuramine dihydrobromide were obtained from Sigma-Aldrich.

\section{General procedure for synthesis of $5 a-m$}

Friedel-Crafts acylation was employed to synthesise the C6-substituted 3-methyl-3,4-dihydroquinazolin-2(1H)-one derivatives. Aluminium trichloride $(4.62 \mathrm{mmol}), 3$-methyl3,4-dihydroquinazolin-2(1H)-one $(3.08 \mathrm{mmol})$ and the appropriate acyl chloride or bromide $(3.08 \mathrm{mmol})$ were dissolved in carbon disulphide $(6 \mathrm{~mL})$. The reaction was heated under reflux $\left(50{ }^{\circ} \mathrm{C}\right)$ for $24 \mathrm{~h}$. The progress of the reaction was monitored by silica gel TLC with ethyl acetate as mobile phase. On completion of the reaction, $30 \mathrm{~mL}$ of a mixture of ice and water was added. The precipitate that formed was collected by filtration and dried in a convection oven overnight. The crude product was purified by recrystallisation from a suitable solvent (ethanol).

6-Benzoyl-3-methyl-3,4-dihydroquinazolin-2(1H)-one (5a) The title compound was prepared in a yield of $39 \%: \mathrm{mp}$ 235.6-258.4 ${ }^{\circ} \mathrm{C} .{ }^{1} \mathrm{H}$ NMR (600 MHz, DMSO) $\delta 9.69$ (s, 1H), $7.66(\mathrm{~d}, J=7.6 \mathrm{~Hz}, 2 \mathrm{H}), 7.63(\mathrm{t}, J=7.4 \mathrm{~Hz}, 1 \mathrm{H}), 7.57$ (d, $J=8.3 \mathrm{~Hz}, 1 \mathrm{H}), 7.54-7.51(\mathrm{~m}, 3 \mathrm{H}), 6.87(\mathrm{~d}, J=8.3 \mathrm{~Hz}, 1 \mathrm{H})$, 4.46 (s, 2H), 2.85 (d, $J=11.5 \mathrm{~Hz}, 3 \mathrm{H}) .{ }^{13} \mathrm{C} \mathrm{NMR}(151 \mathrm{MHz}$, DMSO) $\delta 194.18,153.08,142.20,137.78,132.02,130.72$, 129.47, 129.25, 128.44, 127.93, 117.72, 112.94, 49.41, 33.88; APCI-HRMS $m / z$ calcd for $\mathrm{C}_{16} \mathrm{H}_{14} \mathrm{~N}_{2} \mathrm{O}_{2}\left(\mathrm{MH}^{+}\right)$, 267.1128, found 267.1124. Purity (HPLC): $96 \%$.

\section{3-Methyl-6-(2-phenylacetyl)-3,4-dihydroquinazolin-2(1H)-one}

(5b) The title compound was prepared in a yield of $53 \%$ : mp 259.4-259.5 ${ }^{\circ} \mathrm{C} .{ }^{1} \mathrm{H}$ NMR (600 MHz, DMSO) $\delta 9.66$ (s, 1H), $7.88(\mathrm{dd}, J=8.4,1.6 \mathrm{~Hz}, 1 \mathrm{H}), 7.82(\mathrm{~s}, 1 \mathrm{H}), 7.30(\mathrm{t}$, $J=7.5 \mathrm{~Hz}, 2 \mathrm{H}), 7.26(\mathrm{~d}, J=7.1 \mathrm{~Hz}, 2 \mathrm{H}), 7.23(\mathrm{~d}, J=7.2 \mathrm{~Hz}$, $1 \mathrm{H}), 6.85$ (d, J=8.4 Hz, 1H), 4.47 (s, 2H), 4.27 (s, 2H), 2.87 (s, 3H). ${ }^{13} \mathrm{C}$ NMR (151 MHz, DMSO) $\delta$ 196.25, 153.49, 142.81, 135.94, 130.07, 129.83, 129.75, 128.77, $126.99,126.87,118.18,113.48,49.96,44.71,34.37$; APCIHRMS $m / z$ calcd for $\mathrm{C}_{17} \mathrm{H}_{17} \mathrm{~N}_{2} \mathrm{O}_{2}\left(\mathrm{MH}^{+}\right), 281.1285$, found 281.1285. Purity (HPLC): $92.8 \%$.

6-(Cyclohexanecarbonyl)-3-methyl-3,4-dihydroquinazolin-2(1H)-one (5c) The title compound was prepared in a yield of 39\%: mp 207.3-242.2 ${ }^{\circ} \mathrm{C}$. ${ }^{1} \mathrm{H}$ NMR $(600 \mathrm{MHz}$, DMSO) $\delta 9.62(\mathrm{~s}, 1 \mathrm{H}), 7.78(\mathrm{dd}, J=8.4,1.6 \mathrm{~Hz}, 1 \mathrm{H}), 7.73$ $(\mathrm{s}, 1 \mathrm{H}), 6.84(\mathrm{~d}, J=8.4 \mathrm{~Hz}, 1 \mathrm{H}), 4.47$ (s, 2H), 3.29 (dd, $J=12.6,9.7 \mathrm{~Hz}, 1 \mathrm{H}), 2.87$ (s, 3H), 1.80-1.70 (m, 4H), 1.67 $(\mathrm{d}, J=12.8 \mathrm{~Hz}, 1 \mathrm{H}), 1.36(\mathrm{ddd}, J=23.4,17.3,10.8 \mathrm{~Hz}$, $4 \mathrm{H}), 1.18(\mathrm{~d}, J=12.6 \mathrm{~Hz}, 1 \mathrm{H}) .{ }^{13} \mathrm{C} \mathrm{NMR}(151 \mathrm{MHz}$, DMSO) $\delta 201.74,153.56,142.56,129.28,129.22,126.69$, 118.23, 113.54, 49.99, 44.41, 34.37, 29.70, 26.10, 25.69;
APCI-HRMS $m / z$ calcd $\mathrm{C}_{16} \mathrm{H}_{21} \mathrm{~N}_{2} \mathrm{O}_{2}\left(\mathrm{MH}^{+}\right), 273.1597$, found 273.1583. Purity (HPLC): $98.8 \%$.

6-(4-Chlorobenzoyl)-3-methyl-3,4-dihydroquinazolin-2(1H)-one (5d) The title compound was prepared in a yield of $69 \%$ : mp 236.3-242.1 ${ }^{\circ} \mathrm{C}$. ${ }^{1} \mathrm{H}$ NMR $(600 \mathrm{MHz}$, DMSO) $\delta 9.71(\mathrm{~s}, 1 \mathrm{H}), 7.71-7.64(\mathrm{~m}, 2 \mathrm{H}), 7.62-7.52(\mathrm{~m}$, 4H), 6.87 (d, J=8.3 Hz, 1H), $4.46(\mathrm{~s}, 2 \mathrm{H}), 2.86(\mathrm{~s}, 3 \mathrm{H})$. ${ }^{13} \mathrm{C}$ NMR (151 MHz, DMSO) $\delta$ 193.04, 153.04, 142.39, 136.87, 136.47, 131.14, 130.73, 129.13, 128.56, 127.97, 117.78, 112.99, 49.39, 33.88; APCI-HRMS $m / z$ calcd for $\mathrm{C}_{16} \mathrm{H}_{14} \mathrm{ClN}_{2} \mathrm{O}_{2}\left(\mathrm{MH}^{+}\right), 301.0738$, found 301.0756. Purity (HPLC): $99.4 \%$.

6-(4-Fluorobenzoyl)-3-methyl-3,4-dihydroquinazolin-2(1H)-one (5e) The title compound was prepared in a yield of 64\%: mp 233.6-236.2 ${ }^{\circ} \mathrm{C}$. ${ }^{1} \mathrm{H}$ NMR $(600 \mathrm{MHz}$, DMSO) $\delta 9.69(\mathrm{~s}, 1 \mathrm{H}), 7.81-7.68(\mathrm{~m}, 2 \mathrm{H}), 7.58-7.51(\mathrm{~m}$, 2H), 7.40-7.28 (m, 2H), 6.87 (d, $J=8.3 \mathrm{~Hz}, 1 \mathrm{H}), 4.46$ (s, 2H), $2.85(\mathrm{~d}, J=12.4 \mathrm{~Hz}, 3 \mathrm{H}) .{ }^{13} \mathrm{C} \mathrm{NMR}(151 \mathrm{MHz}$, DMSO) $\delta 192.85,165.12,163.46,153.08,142.24,134.30$, $132.18,132.11,130.68,129.38,127.91,117.76,115.57$, 115.42, 112.96, 49.41, 33.89; APCI-HRMS $m / z$ calcd for $\mathrm{C}_{16} \mathrm{H}_{14} \mathrm{FN}_{2} \mathrm{O}_{2}\left(\mathrm{MH}^{+}\right), 285.1033$, found 285.1059. Purity (HPLC): $98.9 \%$.

6-(2-Fluorobenzoyl)-3-methyl-3,4-dihydroquinazolin-2(1H)-one (5f) The title compound was prepared in a yield of 52\%: mp 268.3-268.5 ${ }^{\circ} \mathrm{C}$. ${ }^{1} \mathrm{H}$ NMR $(600 \mathrm{MHz}$, DMSO) $\delta 9.74(\mathrm{~s}, 1 \mathrm{H}), 7.62(\mathrm{~d}, J=8.3 \mathrm{~Hz}, 1 \mathrm{H}), 7.58-7.51$ (m, 2H), 7.49 (dd, $J=7.4,1.7 \mathrm{~Hz}, 1 \mathrm{H}), 7.38-7.31(\mathrm{~m}, 2 \mathrm{H})$, $6.86(\mathrm{~d}, J=8.4 \mathrm{~Hz}, 1 \mathrm{H}), 4.45(\mathrm{~s}, 2 \mathrm{H}), 2.84(\mathrm{~s}, 3 \mathrm{H}) .{ }^{13} \mathrm{C}$ NMR (151 MHz, DMSO) $\delta 190.81,159.72,158.08,152.93$, $143.11,132.94,132.89,130.55,130.06,130.04,129.50$, $127.57,127.05,126.95,124.74,124.72,117.95,116.23$, 116.09, 113.19, 49.30, 33.86; APCI-HRMS $m / z$ calcd for $\mathrm{C}_{16} \mathrm{H}_{14} \mathrm{FN}_{2} \mathrm{O}_{2}\left(\mathrm{MH}^{+}\right), 285.1033$, found 285.1021. Purity (HPLC): 99.2\%.

6-(3-Fluorobenzoyl)-3-methyl-3,4-dihydroquinazolin-2(1H)-one (5g) The title compound was prepared in a yield of $81 \%$ : mp 243.9-354.9 ${ }^{\circ} \mathrm{C}$. ${ }^{1} \mathrm{H}$ NMR $(600 \mathrm{MHz}$, DMSO) $\delta 9.72$ (s, 1H), 7.58 (ddd, $J=13.7,8.0,4.6 \mathrm{~Hz}, 3 \mathrm{H}$ ), $7.52-7.42(\mathrm{~m}, 3 \mathrm{H}), 6.88(\mathrm{~d}, J=8.3 \mathrm{~Hz}, 1 \mathrm{H}), 4.47$ (s, 2H), 2.86 (s, 3H). ${ }^{13} \mathrm{C}$ NMR (151 MHz, DMSO) $\delta 192.78,162.62$, $160.99,153.01,142.52,140.12,140.08,130.83,130.67$, $130.62,128.92,128.03,125.41,118.91,118.77,117.82$, $115.74,115.59,113.03,49.37,33.87$; APCI-HRMS $m / z$ calcd for $\mathrm{C}_{16} \mathrm{H}_{14} \mathrm{FN}_{2} \mathrm{O}_{2}\left(\mathrm{MH}^{+}\right), 285.1033$, found 285.1017 . Purity (HPLC): $99.0 \%$.

6-(Furan-2-carbonyl)-3-methyl-3,4-dihydroquinazolin-2(1H)-one (5h) The title compound was prepared in 
a yield of $100 \%$ : mp $244.8-248.2{ }^{1} \mathrm{H}$ NMR $(600 \mathrm{MHz}$, DMSO) $\delta 9.72(\mathrm{~s}, 1 \mathrm{H}), 8.09(\mathrm{dd}, J=1.7,0.7 \mathrm{~Hz}, 1 \mathrm{H}), 7.79$ $(\mathrm{dd}, J=8.4,1.7 \mathrm{~Hz}, 1 \mathrm{H}), 7.74(\mathrm{~s}, 1 \mathrm{H}), 7.39(\mathrm{~d}, J=3.5 \mathrm{~Hz}$, $1 \mathrm{H}), 6.92(\mathrm{~d}, J=8.4 \mathrm{~Hz}, 1 \mathrm{H}), 6.78(\mathrm{dd}, J=3.6,1.7 \mathrm{~Hz}, 1 \mathrm{H})$, 4.51 (s, 2H), 2.88 (s, 3H). ${ }^{13} \mathrm{C}$ NMR (151 MHz, DMSO) $\delta 180.24,153.54,151.98,148.40,142.68,130.29,129.84$, $127.68,120.74,118.25,113.57,112.99,49.95,34.39$; APCIHRMS $m / z$ calcd for $\mathrm{C}_{14} \mathrm{H}_{13} \mathrm{~N}_{2} \mathrm{O}_{3}\left(\mathrm{MH}^{+}\right), 257.0920$, found 257.0902. Purity (HPLC): $99.3 \%$.

6-(2-Chloroacetyl)-3-methyl-3,4-dihydroquinazolin-2(1H)-one (5i) The title compound was prepared in a yield of $81 \%$ : mp 249.8-252.1 ${ }^{\circ} \mathrm{C} .{ }^{1} \mathrm{H}$ NMR (600 MHz, DMSO) $\delta 9.72$ $(\mathrm{s}, 1 \mathrm{H}), 7.80(\mathrm{dd}, J=8.4,1.9 \mathrm{~Hz}, 1 \mathrm{H}), 7.76(\mathrm{~s}, 1 \mathrm{H}), 6.85(\mathrm{~d}$, $J=8.4 \mathrm{~Hz}, 1 \mathrm{H}), 5.07(\mathrm{~s}, 2 \mathrm{H}), 4.47(\mathrm{~s}, 2 \mathrm{H}), 2.88(\mathrm{~s}, 3 \mathrm{H}) .{ }^{13} \mathrm{C}$ NMR (151 MHz, DMSO) $\delta 190.11,153.39,143.35,129.70$, $127.66,126.97,118.27,113.53,49.87,47.60,34.37$; APCIHRMS $m / z$ calcd for $\mathrm{C}_{11} \mathrm{H}_{12} \mathrm{ClN}_{2} \mathrm{O}_{2}\left(\mathrm{MH}^{+}\right), 239.0581$, found 239.0584. Purity (HPLC): $99.4 \%$.

6-(3-Chloropropanoyl)-3-methyl-3,4-dihydroquinazolin-2(1H)-one $(5 j)$ The title compound was prepared in a yield of $79 \%$ : mp $171.7-171.8{ }^{\circ} \mathrm{C} .{ }^{1} \mathrm{H}$ NMR $(600 \mathrm{MHz}$, DMSO) $\delta 9.68(\mathrm{~s}, 1 \mathrm{H}), 7.80(\mathrm{dd}, J=8.4,1.9 \mathrm{~Hz}, 1 \mathrm{H})$, $7.76(\mathrm{~s}, 1 \mathrm{H}), 6.84(\mathrm{~d}, J=8.4 \mathrm{~Hz}, 1 \mathrm{H}), 4.47(\mathrm{~s}, 2 \mathrm{H}), 3.91$ (t, $J=6.3 \mathrm{~Hz}, 2 \mathrm{H}), 3.44(\mathrm{t}, J=6.3 \mathrm{~Hz}, 2 \mathrm{H}), 2.88(\mathrm{~s}, 3 \mathrm{H})$. ${ }^{13} \mathrm{C}$ NMR (151 MHz, DMSO) $\delta 195.36,153.47,142.99$, $129.84,129.26,126.65,118.15,113.50,49.93,34.38$; APCIHRMS $m / z$ calcd for $\mathrm{C}_{12} \mathrm{H}_{14} \mathrm{ClN}_{2} \mathrm{O}_{2}\left(\mathrm{MH}^{+}\right), 253.0738$, found 253.0736. Purity (HPLC): $96.3 \%$.

6-(4-Chlorobutanoyl)-3-methyl-3,4-dihydroquinazolin-2 $(1 \mathrm{H})$-one $(\mathbf{5 k})$ The title compound was prepared in a yield of $57 \%$ : mp $180.8-238.3{ }^{\circ} \mathrm{C} .{ }^{1} \mathrm{H}$ NMR $(600 \mathrm{MHz}$, DMSO) $\delta 9.65(\mathrm{~s}, 1 \mathrm{H}), 7.79(\mathrm{dd}, J=8.4,1.8 \mathrm{~Hz}, 1 \mathrm{H})$, $7.74(\mathrm{~s}, 1 \mathrm{H}), 6.84(\mathrm{~d}, J=8.4 \mathrm{~Hz}, 1 \mathrm{H}), 4.47(\mathrm{~s}, 2 \mathrm{H}), 3.70$ $(\mathrm{t}, J=6.7 \mathrm{~Hz}, 2 \mathrm{H}), 3.08(\mathrm{t}, J=7.1 \mathrm{~Hz}, 2 \mathrm{H}), 2.87(\mathrm{~s}, 3 \mathrm{H})$, $2.08-2.02(\mathrm{~m}, 2 \mathrm{H}) .{ }^{13} \mathrm{C}$ NMR (151 MHz, DMSO) $\delta 197.46$, 153.52, 142.76, 130.03, 129.06, 126.47, 118.11, 113.47, 49.95, 45.44, 35.13, 34.37, 27.47; APCI-HRMS $m / z$ calcd for $\mathrm{C}_{13} \mathrm{H}_{16} \mathrm{ClN}_{2} \mathrm{O}_{2}\left(\mathrm{MH}^{+}\right), 267.0894$, found 267.0896. Purity (HPLC): 94.5\%.

6-Acetyl-3-methyl-3,4-dihydroquinazolin-2(1H)-one (5I) The title compound was prepared in a yield of 76\%: $\mathrm{mp} 213.3-$ $224.8^{\circ} \mathrm{C} .{ }^{1} \mathrm{H}$ NMR (600 MHz, DMSO) $\delta 9.65(\mathrm{~s}, 1 \mathrm{H}), 7.77$ $(\mathrm{dd}, J=8.3,1.9 \mathrm{~Hz}, 1 \mathrm{H}), 7.72(\mathrm{~s}, 1 \mathrm{H}), 6.83(\mathrm{~d}, J=8.3 \mathrm{~Hz}$, 1H), 4.47 (s, 2H), 2.87 (s, 3H), 2.48 (s, 3H). ${ }^{13} \mathrm{C} \mathrm{NMR}$ (151 MHz, DMSO) $\delta 196.47,153.53,142.69,130.48$, 129.39, 126.74, 118.03, 113.40, 49.95, 34.37, 26.77; APCIHRMS $m / z$ calcd for $\mathrm{C}_{11} \mathrm{H}_{13} \mathrm{~N}_{2} \mathrm{O}_{2}\left(\mathrm{MH}^{+}\right), 205.0971$, found 205.0973. Purity (HPLC): $98.9 \%$.
3-Methyl-6-propionyl-3,4-dihydroquinazolin-2(1H)-one $(\mathbf{5 m})$ The title compound was prepared in a yield of 80\%: mp 301.0-312.6 ${ }^{\circ} \mathrm{C} .{ }^{1} \mathrm{H}$ NMR (600 MHz, DMSO) $\delta$ $9.63(\mathrm{~s}, 1 \mathrm{H}), 7.78(\mathrm{~d}, J=8.4 \mathrm{~Hz}, 1 \mathrm{H}), 7.73(\mathrm{~s}, 1 \mathrm{H}), 6.83$ $(\mathrm{d}, J=8.4 \mathrm{~Hz}, 1 \mathrm{H}), 4.47(\mathrm{~s}, 2 \mathrm{H}), 2.94(\mathrm{q}, J=7.2 \mathrm{~Hz}, 2 \mathrm{H})$, $2.87(\mathrm{~s}, 3 \mathrm{H}), 1.06(\mathrm{t}, J=7.2 \mathrm{~Hz}, 3 \mathrm{H}) .{ }^{13} \mathrm{C}$ NMR $(151 \mathrm{MHz}$, DMSO) $\delta 199.03,153.57,142.54,130.16,128.99,126.37$, 118.05, 113.42, 49.98, 34.37, 31.17, 8.83; APCI-HRMS m/z calcd for $\mathrm{C}_{12} \mathrm{H}_{15} \mathrm{~N}_{2} \mathrm{O}_{2}\left(\mathrm{MH}^{+}\right), 219.1128$, found 219.1137 . Purity (HPLC): $99.1 \%$.

\section{General procedure for preparation of compounds 6a-m}

6-Acetyl-3-methyl-3,4-dihydroquinazolin-2(1H)-one (51) for the synthesis of $\mathbf{6 a}$ and $\mathbf{6 c - m}$ or 3-methyl-6-propionyl3,4-dihydroquinazolin-2(1H)-one $\mathbf{( 5 m})(1.375 \mathrm{mmol})$ for the synthesis of $\mathbf{6 b}$ and the appropriate benzaldehyde (or cinnamaldehyde for $\mathbf{6 c})(1.375 \mathrm{mmol})$ were dissolved in a mixture of hydrochloric acid $(32 \% ; 5.5 \mathrm{~mL})$ and methanol $(3.67 \mathrm{~mL})$. The reaction was heated under reflux for 24 to $48 \mathrm{~h}$, and the progress was monitored by using silica gel TLC with ethyl acetate as the mobile phase. Upon completion, $30 \mathrm{~mL}$ of a mixture of ice and water was added to the reaction. The residue that formed was collected by filtration and dried in a convection oven overnight. The crude product was purified by recrystallisation from ethanol.

6-Cinnamoyl-3-methyl-3,4-dihydroquinazolin-2(1H)-one (6a) The title compound was prepared in a yield of $40 \%: \mathrm{mp}$ 249.9-250.0 ${ }^{\circ} \mathrm{C} .{ }^{1} \mathrm{H}$ NMR $(600 \mathrm{MHz}, \mathrm{DMSO}) \delta 9.70(\mathrm{~s}, 1 \mathrm{H})$, 8.04-7.97 (m, 2H), 7.95-7.85 (m, 3H), $7.71(\mathrm{~d}, J=15.6 \mathrm{~Hz}$, $1 \mathrm{H}), 7.57-7.44(\mathrm{~m}, 3 \mathrm{H}), 6.89(\mathrm{~d}, J=8.4 \mathrm{~Hz}, 1 \mathrm{H}), 4.52(\mathrm{~s}$, 2H), 2.90 (s, 3H). ${ }^{13} \mathrm{C}$ NMR (151 MHz, DMSO) $\delta 187.45$, $153.49,143.50,142.85,135.32,131.06,130.91,129.80$, 129.38, 129.22, 127.28, 122.42, 118.28, 113.61, 50.03, 34.42; APCI-HRMS $\mathrm{m} / \mathrm{z}$ calcd for $\mathrm{C}_{18} \mathrm{H}_{17} \mathrm{~N}_{2} \mathrm{O}_{2}\left(\mathrm{MH}^{+}\right)$, 293.1284, found 293.1281. Purity (HPLC): $91.9 \%$.

(Z)-3-Methyl-6-(2-methyl-3-phenylacryloyl)-3,4-dihydroquinazolin-2(1H)-one (6b) The title compound was prepared in a yield of $17 \%$ : mp $122.8-122.9{ }^{\circ} \mathrm{C} .{ }^{1} \mathrm{H}$ NMR $(600 \mathrm{MHz}$, DMSO) $\delta 9.64(\mathrm{~s}, 1 \mathrm{H}), 7.61(\mathrm{dd}, J=8.3,1.8 \mathrm{~Hz}, 1 \mathrm{H}), 7.56$ $(\mathrm{s}, 1 \mathrm{H}), 7.51(\mathrm{~d}, J=7.4 \mathrm{~Hz}, 2 \mathrm{H}), 7.45(\mathrm{t}, J=7.7 \mathrm{~Hz}, 2 \mathrm{H})$, 7.38 (d, $J=7.3 \mathrm{~Hz}, 1 \mathrm{H}), 7.05(\mathrm{~s}, 1 \mathrm{H}), 6.87(\mathrm{~d}, J=8.3 \mathrm{~Hz}$, $1 \mathrm{H}), 4.49$ (s, 2H), $2.87(\mathrm{~s}, 3 \mathrm{H}), 2.15(\mathrm{~d}, J=1.3 \mathrm{~Hz}, 3 \mathrm{H})$. ${ }^{13} \mathrm{C}$ NMR (151 MHz, DMSO) $\delta$ 197.38, 153.64, 142.16, $139.32,136.65,135.95,130.74,130.55,130.12,128.97$, $128.92,128.04,118.09,113.32,49.96,34.36,15.34$; APCIHRMS $m / z$ calcd for $\mathrm{C}_{19} \mathrm{H}_{19} \mathrm{~N}_{2} \mathrm{O}_{2}\left(\mathrm{MH}^{+}\right), 307.1441$, found 307.1436. Purity (HPLC): $91.8 \%$. 
3-Methyl-6-((2E,4Z)-5-phenylpenta-2,4-dienoyl)-3,4-dihydroquinazolin-2(1H)-one $(6 \mathrm{c})$ The title compound was prepared in a yield of $68 \%$ : $\mathrm{mp} 243.7-247.2{ }^{\circ} \mathrm{C} .{ }^{1} \mathrm{H}$ NMR $(600 \mathrm{MHz}$, DMSO) $\delta 9.70(\mathrm{~s}, 1 \mathrm{H}), 7.87(\mathrm{dd}, J=8.4,1.7 \mathrm{~Hz}, 1 \mathrm{H})$, $7.83(\mathrm{~s}, 1 \mathrm{H}), 7.60(\mathrm{~d}, J=7.3 \mathrm{~Hz}, 2 \mathrm{H}), 7.55-7.44(\mathrm{~m}, 1 \mathrm{H})$, 7.44-7.30 (m, 4H), 7.27-7.18 (m, 2H), 6.88 (d, J=8.4 Hz, $1 \mathrm{H}), 4.51$ (s, 2H), 2.89 (s, 3H). ${ }^{13} \mathrm{C}$ NMR (151 MHz, DMSO) $\delta 187.48,153.49,143.92,142.72,141.64,136.56$, $131.14,129.62,129.43,127.79,127.68,126.88,125.86$, 118.33, 113.62, 50.00, 34.40; APCI-HRMS $m / z$ calcd for $\mathrm{C}_{20} \mathrm{H}_{19} \mathrm{~N}_{2} \mathrm{O}_{2}\left(\mathrm{MH}^{+}\right), 319.1441$, found 319.1449. Purity (HPLC): $99.6 \%$.

(E)-6-(3-(4-Methoxyphenyl)acryloyl)-3-methyl-3,4-dihydroquinazolin-2(1H)-one $(\mathbf{6 d})$ The title compound was prepared in a yield of 47\%: $\mathrm{mp} 220.3-331.9^{\circ} \mathrm{C}$. ${ }^{1} \mathrm{H}$ NMR $(600 \mathrm{MHz}$, DMSO) $\delta 9.70(\mathrm{~s}, 1 \mathrm{H}), 8.03(\mathrm{dd}, J=8.4,1.7 \mathrm{~Hz}, 1 \mathrm{H}), 7.98$ $(\mathrm{s}, 1 \mathrm{H}), 7.91(\mathrm{~d}, J=15.6 \mathrm{~Hz}, 1 \mathrm{H}), 7.68(\mathrm{~d}, J=15.5 \mathrm{~Hz}$, $1 \mathrm{H}), 7.48-7.40(\mathrm{~m}, 2 \mathrm{H}), 7.37(\mathrm{t}, J=7.9 \mathrm{~Hz}, 1 \mathrm{H}), 7.02(\mathrm{dd}$, $J=8.1,2.4 \mathrm{~Hz}, 1 \mathrm{H}), 6.90(\mathrm{~d}, J=8.4 \mathrm{~Hz}, 1 \mathrm{H}), 4.52$ (s, 2H), 3.83 (s, 3H), 2.90 (s, 3H). ${ }^{13} \mathrm{C}$ NMR (151 MHz, DMSO) $\delta 187.46,160.12,153.48,143.50,142.86,136.72,131.05$, 130.39, 129.86, 127.26, 122.67, 121.94, 118.28, 116.84, 113.93, 113.59, 55.78, 50.04, 34.41; APCI-HRMS m/z calcd for $\mathrm{C}_{19} \mathrm{H}_{19} \mathrm{~N}_{2} \mathrm{O}_{3}\left(\mathrm{MH}^{+}\right), 323.1390$, found 323.1389. Purity (HPLC): 96.4\%.

(E)-6-(3-(4-Hydroxyphenyl)acryloyl)-3-methyl-3,4-dihydroquinazolin-2(1H)-one (6e) The title compound was prepared in a yield of 16\%: $\mathrm{mp} 290.9-294.8{ }^{\circ} \mathrm{C}$. ${ }^{1} \mathrm{H} \mathrm{NMR}(600 \mathrm{MHz}$, DMSO) $\delta 10.07(\mathrm{~s}, 1 \mathrm{H}), 9.67(\mathrm{~s}, 1 \mathrm{H}), 8.00-7.92(\mathrm{~m}, 2 \mathrm{H})$, $7.71(\mathrm{dd}, J=12.0,10.4 \mathrm{~Hz}, 3 \mathrm{H}), 7.64(\mathrm{~d}, J=15.4 \mathrm{~Hz}, 1 \mathrm{H})$, $6.88(\mathrm{~d}, J=8.3 \mathrm{~Hz}, 1 \mathrm{H}), 6.84(\mathrm{~d}, J=8.6 \mathrm{~Hz}, 2 \mathrm{H}), 4.51(\mathrm{~s}$, 2H), 2.89 (s, 3H). ${ }^{13} \mathrm{C}$ NMR (151 MHz, DMSO) $\delta 187.33$, $160.41,153.53,143.95,142.53,131.44,131.28,129.54$, 127.04, 126.42, 118.83, 118.19, 116.26, 113.54, 56.51, 50.06, 34.41, 19.06; APCI-HRMS $m / z$ calcd for $\mathrm{C}_{18} \mathrm{H}_{17} \mathrm{~N}_{2} \mathrm{O}_{3}$ $\left(\mathrm{MH}^{+}\right), 309.1233$, found 308.1145. Purity (HPLC): $98.9 \%$.

(E)-6-(3-(4-Chlorophenyl)acryloyl)-3-methyl-3,4-dihydroquinazolin-2(1H)-one (6f) The title compound was prepared in a yield of $42 \%$ : mp $244.3-256.6{ }^{\circ} \mathrm{C}$. ${ }^{1} \mathrm{H}$ NMR $(600 \mathrm{MHz}$, DMSO) $\delta 9.70(\mathrm{~s}, 1 \mathrm{H}), 8.02(\mathrm{dd}, J=8.4,1.8 \mathrm{~Hz}, 1 \mathrm{H}), 7.98$ $(\mathrm{s}, 1 \mathrm{H}), 7.92(\mathrm{t}, J=12.1 \mathrm{~Hz}, 3 \mathrm{H}), 7.69(\mathrm{~d}, J=15.6 \mathrm{~Hz}, 1 \mathrm{H})$, $7.53(\mathrm{~d}, J=8.5 \mathrm{~Hz}, 2 \mathrm{H}), 6.89(\mathrm{~d}, J=8.4 \mathrm{~Hz}, 1 \mathrm{H}), 4.52(\mathrm{~s}$, $2 \mathrm{H}), 2.88(\mathrm{~d}, J=13.3 \mathrm{~Hz}, 3 \mathrm{H}) .{ }^{13} \mathrm{C}$ NMR (151 MHz, DMSO) $\delta 187.32,153.46,142.91,142.02,135.35,134.31,130.96$, 130.91, 129.86, 129.41, 127.30, 123.16, 118.29, 113.60, 50.02, 34.41; APCI-HRMS $m / z$ calcd for $\mathrm{C}_{18} \mathrm{H}_{16} \mathrm{ClN}_{2} \mathrm{O}_{2}$ $\left(\mathrm{MH}^{+}\right), 327.0894$, found 327.0864. Purity (HPLC): $75.4 \%$.

(E) - 4- (3- (3-Methyl-2-oxo-1,2,3,4-tetrahydroquinazolin-6-yl)-3-oxoprop-1-en-1-yl)benzonitrile (6g) The title compound was prepared in a yield of $13 \%$ : mp 220.9 $224.8^{\circ} \mathrm{C}$. ${ }^{1} \mathrm{H}$ NMR (600 MHz, DMSO) $\delta 9.72$ (s, 1H), 8.10$8.06(\mathrm{~m}, 2 \mathrm{H}), 8.05-8.03(\mathrm{~m}, 1 \mathrm{H}), 8.03-8.01(\mathrm{~m}, 1 \mathrm{H}), 8.00$ $7.92(\mathrm{~m}, 3 \mathrm{H}), 7.73(\mathrm{~d}, J=15.6 \mathrm{~Hz}, 1 \mathrm{H}), 6.89(\mathrm{~d}, J=8.4 \mathrm{~Hz}$, 1H), $4.52(\mathrm{~s}, 2 \mathrm{H}), 2.90(\mathrm{~s}, 3 \mathrm{H}) .{ }^{13} \mathrm{C} \mathrm{NMR}(151 \mathrm{MHz}$, DMSO) $\delta 187.25,153.42,143.11,141.28,139.92,133.19$, $130.76,130.02,129.95,129.78,127.44,125.74,118.34$, 113.64, 112.60, 50.01, 34.42; APCI-HRMS $m / z$ calcd for $\mathrm{C}_{19} \mathrm{H}_{16} \mathrm{~N}_{3} \mathrm{O}_{2}\left(\mathrm{MH}^{+}\right), 318.1237$, found 318.1250 . Purity (HPLC): $76.5 \%$.

(E)-3-Methyl-6-(3-(4-(trifluoromethyl)phenyl)acryloyl)-3,4-dihydroquinazolin-2(1H)-one $(\mathbf{6} \boldsymbol{h})$ The title compound was prepared in a yield of $26 \%$ : mp $216.9-252.0{ }^{\circ} \mathrm{C}$. ${ }^{1} \mathrm{H}$ NMR (600 MHz, DMSO) $\delta 9.72(\mathrm{~s}, 1 \mathrm{H}), 8.09(\mathrm{~d}, J=8.2 \mathrm{~Hz}, 2 \mathrm{H})$, 8.07-8.02 (m, 2H), $8.00(\mathrm{~s}, 1 \mathrm{H}), 7.81(\mathrm{~d}, J=8.3 \mathrm{~Hz}, 2 \mathrm{H})$, $7.75(\mathrm{~d}, J=15.6 \mathrm{~Hz}, 1 \mathrm{H}), 6.90(\mathrm{~d}, J=8.4 \mathrm{~Hz}, 1 \mathrm{H}), 4.52$ (s, 2H), 2.90 (s, 3H). ${ }^{13} \mathrm{C}$ NMR (151 MHz, DMSO) $\delta 187.30$, 153.43, 143.06, 141.49, 139.37, 130.80, 130.45, 130.24, $129.98,129.76,127.39,126.16,126.14,125.46,125.12$, 123.66, 118.33, 113.63, 50.01, 34.41; APCI-HRMS m/z calcd for $\mathrm{C}_{19} \mathrm{H}_{16} \mathrm{~F}_{3} \mathrm{~N}_{2} \mathrm{O}_{2}\left(\mathrm{MH}^{+}\right), 361.1158$, found 361.1158 . Purity (HPLC): $78.7 \%$.

(E)-6-(3-(3-Chlorophenyl)acryloyl)-3-methyl-3,4-dihydroquinazolin-2(1H)-one (6i) The title compound was prepared in a yield of $49 \%$ : mp $257.7-257.9{ }^{\circ} \mathrm{C}$. ${ }^{1} \mathrm{H}$ NMR (600 MHz, DMSO) $\delta 9.70(\mathrm{~s}, 1 \mathrm{H}), 8.08-8.02(\mathrm{~m}, 2 \mathrm{H})$, $7.99(\mathrm{~d}, J=15.4 \mathrm{~Hz}, 2 \mathrm{H}), 7.80(\mathrm{~d}, J=6.9 \mathrm{~Hz}, 1 \mathrm{H}), 7.68(\mathrm{~d}$, $J=15.6 \mathrm{~Hz}, 1 \mathrm{H}), 7.49(\mathrm{t}, J=4.8 \mathrm{~Hz}, 2 \mathrm{H}), 6.89$ (d, $J=8.4 \mathrm{~Hz}$, $1 \mathrm{H}), 4.52$ (s, 2H), 2.90 (s, 3H). ${ }^{13} \mathrm{C}$ NMR (151 MHz, DMSO) $\delta 187.30,153.45,142.98,141.78,137.60,134.27,131.15$, $130.90,130.43,129.95,128.27,128.24,127.37,123.96$, 118.29, 113.61, 50.04, 34.42; APCI-HRMS $m / z$ calcd for $\mathrm{C}_{18} \mathrm{H}_{16} \mathrm{ClN}_{2} \mathrm{O}_{2}\left(\mathrm{MH}^{+}\right), 327.0894$, found 327.0884. Purity (HPLC): 93.2\%.

(E)-6-(3-(2-Chlorophenyl)acryloyl)-3-methyl-3,4-dihydroquinazolin-2(1H)-one (6j) The title compound was prepared in a yield of 56\%: $\mathrm{mp} 257.6-265.1{ }^{\circ} \mathrm{C} .{ }^{1} \mathrm{H} \mathrm{NMR}(600 \mathrm{MHz}$, DMSO) $\delta 9.72(\mathrm{~s}, 1 \mathrm{H}), 8.19(\mathrm{~d}, J=6.6 \mathrm{~Hz}, 1 \mathrm{H}), 7.9-8.0(\mathrm{~m})$, $7.58(\mathrm{~d}, J=6.9 \mathrm{~Hz}, 1 \mathrm{H}), 7.47(\mathrm{~s}, 2 \mathrm{H}), 6.90(\mathrm{~d}, J=8.2 \mathrm{~Hz}$, $1 \mathrm{H}), 4.52$ (s, 2H), 2.90 (s, 3H). ${ }^{13} \mathrm{C}$ NMR (151 MHz, DMSO) $\delta$ 187.20, 153.44, 143.08, 138.06, 134.72, 132.94, 132.31, $130.77,130.52,129.98,128.95,128.14,127.41,125.22$, $118.35,113.65,50.01,34.42$; APCI-HRMS $m / z$ calcd for $\mathrm{C}_{18} \mathrm{H}_{16} \mathrm{ClN}_{2} \mathrm{O}_{2}\left(\mathrm{MH}^{+}\right), 327.0894$, found 327.0900. Purity (HPLC): $92.3 \%$.

(E)-6-(3-(4-Fluorophenyl)acryloyl)-3-methyl-3,4-dihydroquinazolin-2(1H)-one (6k) The title compound was prepared in a yield of $27 \%$ : mp 241.5-253.3 ${ }^{\circ} \mathrm{C}$. ${ }^{1} \mathrm{H}$ NMR (600 MHz, DMSO) $\delta 9.69$ (s, 1H), 8.01 (dd, $J=8.4,1.9 \mathrm{~Hz}$, 
1H), 7.99-7.93 (m, 3H), 7.87 (d, J=15.6 Hz, 1H), 7.71 (d, $J=15.6 \mathrm{~Hz}, 1 \mathrm{H}), 7.31(\mathrm{t}, J=8.8 \mathrm{~Hz}, 2 \mathrm{H}), 6.89(\mathrm{~d}, J=8.4 \mathrm{~Hz}$, $1 \mathrm{H}), 4.52(\mathrm{~s}, 2 \mathrm{H}), 2.90(\mathrm{~s}, 3 \mathrm{H}) .{ }^{13} \mathrm{C} \mathrm{NMR}(151 \mathrm{MHz}$, DMSO) $\delta 187.37,164.60,162.95,153.47,142.84,142.26$, $132.02,132.00,131.56,131.51,131.04,129.81,127.25$, $122.33,118.27,116.46,116.31,113.59,50.04,34.41$; APCIHRMS $m / z$ calcd for $\mathrm{C}_{18} \mathrm{H}_{16} \mathrm{FN}_{2} \mathrm{O}_{2}\left(\mathrm{MH}^{+}\right), 311.1190$, found 310.1112. Purity (HPLC): $95.4 \%$.

(E)-6-(3-(4-Bromophenyl)acryloyl)-3-methyl-3,4-dihydroquinazolin-2(1H)-one (6I) The title compound was prepared in a yield of $15 \%$ : $\mathrm{mp} 260.3-265.0^{\circ} \mathrm{C}$. ${ }^{1} \mathrm{H}$ NMR $(600 \mathrm{MHz}$, DMSO) $\delta 9.70(\mathrm{~s}, 1 \mathrm{H}), 8.01(\mathrm{dd}, J=8.4,1.8 \mathrm{~Hz}, 1 \mathrm{H}), 7.98$ $(\mathrm{s}, 1 \mathrm{H}), 7.94(\mathrm{~d}, J=15.6 \mathrm{~Hz}, 1 \mathrm{H}), 7.84(\mathrm{~d}, J=8.5 \mathrm{~Hz}, 2 \mathrm{H})$, $7.66(\mathrm{~d}, J=8.3 \mathrm{~Hz}, 3 \mathrm{H}), 6.89$ (d, $J=8.4 \mathrm{~Hz}, 1 \mathrm{H}), 4.52$ (s, 2H), 2.90 (s, 3H). ${ }^{13} \mathrm{C}$ NMR (151 MHz, DMSO) $\delta 187.33$, $153.46,142.92,142.12,134.63,132.33,131.13,130.96$, 129.87, 127.31, 124.23, 123.21, 118.29, 113.61, 50.03, 34.42; APCI-HRMS $m / z$ calcd for $\mathrm{C}_{18} \mathrm{H}_{16} \mathrm{BrN}_{2} \mathrm{O}_{2}\left(\mathrm{MH}^{+}\right)$, 371.0389, found 372.0323. Purity (HPLC): $96.8 \%$.

(E)-6-(3-(3-Fluorophenyl)acryloyl)-3-methyl-3,4-dihydroquinazolin-2(1H)-one $(\mathbf{6 m})$ The title compound was prepared in a yield of $23 \%$ : mp 317.3-336.2 ${ }^{\circ} \mathrm{C}$. ${ }^{1} \mathrm{H}$ NMR $(600 \mathrm{MHz}$, DMSO) $\delta 9.70(\mathrm{~s}, 1 \mathrm{H}), 8.03(\mathrm{dd}, J=8.4,1.9 \mathrm{~Hz}, 1 \mathrm{H})$, 8.00-7.95 (m, 2H), $7.83(\mathrm{~d}, J=10.1 \mathrm{~Hz}, 1 \mathrm{H}), 7.72-7.65$ $(\mathrm{m}, 2 \mathrm{H}), 7.50(\mathrm{dd}, J=7.9,1.7 \mathrm{~Hz}, 1 \mathrm{H}), 7.28(\mathrm{~d}, J=2.4 \mathrm{~Hz}$, $1 \mathrm{H}), 6.89$ (d, $J=8.4 \mathrm{~Hz}, 1 \mathrm{H}), 4.52(\mathrm{~s}, 2 \mathrm{H}), 2.90(\mathrm{~s}, 3 \mathrm{H}) .{ }^{13} \mathrm{C}$ NMR (151 MHz, DMSO) $\delta$ 187.33, 163.79, 162.18, 153.45, $142.96,142.02,137.95,137.89,131.33,131.28,130.90$, $129.91,127.36,125.93,123.88,118.28,117.61,117.47$, 115.04, 114.89, 113.62, 50.03, 34.41; APCI-HRMS m/z calcd for $\mathrm{C}_{18} \mathrm{H}_{16} \mathrm{FN}_{2} \mathrm{O}_{2}\left(\mathrm{MH}^{+}\right), 311.1190$, found 311.1200 . Purity (HPLC): $84.6 \%$.

\section{General synthesis of $7 a-e$ and $8 a-f$}

Commercially available 3-methyl-3,4-dihydroquinazolin2(1H)-one $(1.85 \mathrm{mmol})$ and sodium hydride $(3.7 \mathrm{mmol})$ were dissolved in anhydrous DMF. The reaction was stirred for $20 \mathrm{~min}$ at $0{ }^{\circ} \mathrm{C}$. The appropriate alkyl bromide or alkyl chloride $(1.85 \mathrm{mmol})$ was added to the mixture, and stirring was continued for $1 \mathrm{~h}$ at $0{ }^{\circ} \mathrm{C}$. The reaction progress was monitored by TLC with petroleum ether and ethyl acetate $(2: 1)$ as the mobile phase. Upon completion, $30 \mathrm{~mL}$ of a mixture of ice and water was added and the mixture was extracted to $40 \mathrm{~mL}$ ethyl acetate. The organic phase was dried over $\mathrm{MgSO}_{4}$, filtered and evaporated in vacuo. In most instances, the residue was purified by recrystallisation from ethanol, ethyl acetate or from a mixture of petroleum ether and ethyl acetate/ethanol (1:1). Compounds $\mathbf{7 b}, \mathbf{7 c}, \mathbf{7 e}, \mathbf{8 a}$ and $\mathbf{8 c}$ were purified by silica gel column chromatography with a mixture of petroleum ether and ethyl acetate (2:1) serving as mobile phase.

1-(4-Chlorobenzyl)-3-methyl-3,4-dihydroquinazolin-2(1H)-one (7a) The title compound was prepared in a yield of $26 \%: \mathrm{mp}$ 118.9-123.9 ${ }^{\circ} \mathrm{C}$ (ethanol). ${ }^{1} \mathrm{H}$ NMR (600 MHz, $\left.\mathrm{CDCl}_{3}\right) \delta$ 7.28-7.24 (m, 2H), $7.19(\mathrm{~d}, J=8.3 \mathrm{~Hz}, 2 \mathrm{H}), 7.13-7.03(\mathrm{~m}$, 2H), $6.94(\mathrm{t}, J=7.4 \mathrm{~Hz}, 1 \mathrm{H}), 6.63(\mathrm{~d}, J=8.2 \mathrm{~Hz}, 1 \mathrm{H}), 5.08$ (s, 2H), 4.46 (s, 2H), 3.09 (s, 3H). ${ }^{13} \mathrm{C} \mathrm{NMR} \mathrm{(151} \mathrm{MHz,}$ $\left.\mathrm{CDCl}_{3}\right) \delta$ 155.04, 138.40, 136.38, 132.55, 128.79, 128.18, 127.79, 125.57, 121.95, 119.56, 113.69, 50.47, 46.22, 35.83; APCI-HRMS $m / z$ calcd for $\mathrm{C}_{16} \mathrm{H}_{16} \mathrm{ClN}_{2} \mathrm{O}\left(\mathrm{MH}^{+}\right), 287.0945$, found 301.0731. Purity (HPLC): $97.4 \%$.

1-(3-Bromobenzyl)-3-methyl-3,4-dihydroquinazolin-2(1H)-one (7b) The title compound was prepared in a yield of $67 \%$ : mp 96.8-100.1 ${ }^{\circ} \mathrm{C}$ (petroleum ether: ethyl acetate). ${ }^{1} \mathrm{H}$ NMR (600 MHz, $\left.\mathrm{CDCl}_{3}\right) \delta 7.41(\mathrm{~d}, J=8.4 \mathrm{~Hz}, 2 \mathrm{H}), 7.13(\mathrm{~d}$, $J=8.3 \mathrm{~Hz}, 2 \mathrm{H}), 7.09(\mathrm{~d}, J=8.0 \mathrm{~Hz}, 1 \mathrm{H}), 7.06(\mathrm{~d}, J=7.4 \mathrm{~Hz}$, $1 \mathrm{H}), 6.94(\mathrm{t}, J=7.4 \mathrm{~Hz}, 1 \mathrm{H}), 6.62(\mathrm{~d}, J=8.2 \mathrm{~Hz}, 1 \mathrm{H}), 5.06$ (s, 2H), $4.46(\mathrm{~s}, 2 \mathrm{H}), 3.09(\mathrm{~s}, 3 \mathrm{H}) .{ }^{13} \mathrm{C} \mathrm{NMR}(151 \mathrm{MHz}$, $\left.\mathrm{CDCl}_{3}\right) \delta 155.03,138.39,136.93,131.73,128.19,128.16$, 125.58, 121.96, 120.62, 119.56, 113.68, 50.48, 46.27, 35.83; APCI-HRMS $m / z$ calcd for $\mathrm{C}_{16} \mathrm{H}_{16} \mathrm{BrN}_{2} \mathrm{O}\left(\mathrm{MH}^{+}\right), 331.0440$, found 331.0407. Purity (HPLC): $98.4 \%$.

1-(4-Bromobenzyl)-3-methyl-3,4-dihydroquinazolin-2(1H)-one (7c) The title compound was prepared in a yield of 57\%: $\mathrm{mp}$ 095.8-098.6 ${ }^{\circ} \mathrm{C}$ (petroleum ether: ethyl acetate). ${ }^{1} \mathrm{H}$ NMR $\left(600 \mathrm{MHz}, \mathrm{CDCl}_{3}\right) \delta 7.44-7.39(\mathrm{~m}, 2 \mathrm{H}), 7.16-7.03(\mathrm{~m}, 4 \mathrm{H})$, $6.94(\mathrm{td}, J=7.4,0.6 \mathrm{~Hz}, 1 \mathrm{H}), 6.62$ (d, $J=8.2 \mathrm{~Hz}, 1 \mathrm{H}), 5.06$ (s, 2H), $4.46(\mathrm{~s}, 2 \mathrm{H}), 3.09(\mathrm{~s}, 3 \mathrm{H}) .{ }^{13} \mathrm{C} \mathrm{NMR}(151 \mathrm{MHz}$, $\left.\mathrm{CDCl}_{3}\right) \delta 155.02,138.39,136.93,131.73,128.19,128.16$, 125.58, 121.96, 120.62, 119.56, 113.68, 50.47, 46.27, 35.83; APCI-HRMS $m / z$ calcd for $\mathrm{C}_{16} \mathrm{H}_{16} \mathrm{BrN}_{2} \mathrm{O}\left(\mathrm{MH}^{+}\right), 331.0440$, found 331.0440. Purity (HPLC): 99.2\%.

1-(4-lodobenzyl)-3-methyl-3,4-dihydroquinazolin-2(1H)-one (7d) The title compound was prepared in a yield of $11 \%$ : $\mathrm{mp}$ 106.8-109.1 ${ }^{\circ} \mathrm{C}$ (petroleum ether: ethyl acetate). ${ }^{1} \mathrm{H}$ NMR $\left(600 \mathrm{MHz}, \mathrm{CDCl}_{3}\right) \delta 7.61(\mathrm{~d}, J=8.3 \mathrm{~Hz}, 2 \mathrm{H}), 7.12-7.03(\mathrm{~m}$, 2H), 7.01 (d, $J=8.2 \mathrm{~Hz}, 2 \mathrm{H}), 6.95$ (d, $J=7.4 \mathrm{~Hz}, 1 \mathrm{H}), 6.62$ (d, J=8.2 Hz, 1H), 5.06 (s, 2H), 4.46 (s, 2H), 3.09 (s, 3H), $1.65(\mathrm{~s}, 1 \mathrm{H}) .{ }^{13} \mathrm{C} \mathrm{NMR}\left(151 \mathrm{MHz}, \mathrm{CDCl}_{3}\right) \delta 155.02,138.39$, 137.68, 137.65, 128.44, 128.20, 125.58, 121.96, 119.56, 113.68, 92.07, 50.47, 46.35, 35.84; APCI-HRMS $m / z$ calcd for $\mathrm{C}_{16} \mathrm{H}_{16} \mathrm{IN}_{2} \mathrm{O}\left(\mathrm{MH}^{+}\right), 379.0301$, found 379.0278 . Purity (HPLC): $95.4 \%$.

3-Methyl-1-(4-(triflouromethyl)benzyl)-3,4-dihydroquinazolin-2(1H)-one (7e) The title compound was prepared in a yield of $25 \%$ : $\mathrm{mp} 086.4-088.9^{\circ} \mathrm{C}$ (petroleum ether: ethyl acetate). ${ }^{1} \mathrm{H} \mathrm{NMR}\left(600 \mathrm{MHz}, \mathrm{CDCl}_{3}\right) \delta 7.53(\mathrm{~s}, 1 \mathrm{H})$, 
7.51-7.45 (m, 1H), $7.41(\mathrm{~d}, J=6.4 \mathrm{~Hz}, 2 \mathrm{H}), 7.13-7.05(\mathrm{~m}$, $2 \mathrm{H}), 6.95(\mathrm{td}, J=7.4,0.7 \mathrm{~Hz}, 1 \mathrm{H}), 6.61(\mathrm{~d}, J=8.2 \mathrm{~Hz}, 1 \mathrm{H})$, 5.17 (s, 2H), 4.48 (s, 2H), 3.10 (s, 3H). ${ }^{13} \mathrm{C} \mathrm{NMR}(151 \mathrm{MHz}$, $\left.\mathrm{CDCl}_{3}\right) \delta 154.99,139.01,138.36,129.67,129.18,128.27$, $125.67,123.89,123.86,123.21,123.19,123.17,122.07$, 119.58, 113.56, 50.48, 46.52, 35.86; APCI-HRMS m/z calcd for $\mathrm{C}_{17} \mathrm{H}_{16} \mathrm{~F}_{3} \mathrm{~N}_{2} \mathrm{O}\left(\mathrm{MH}^{+}\right), 321.1209$, found 321.1240. Purity (HPLC): $99.1 \%$.

1-(3-Chlorobenzyl)-3-methyl-3,4-dihydroquinazolin-2(1H,3H)-dione (8a) The title compound was prepared in a yield of $15 \%$ : $\mathrm{mp} 127.6-130.0^{\circ} \mathrm{C}$ (petroleum ether: ethyl acetate). ${ }^{1} \mathrm{H} \mathrm{NMR}\left(600 \mathrm{MHz}, \mathrm{CDCl}_{3}\right) \delta 8.26(\mathrm{dd}, J=7.9$, $1.4 \mathrm{~Hz}, 1 \mathrm{H}$ ), 7.57 (ddd, $J=8.6,7.3,1.6 \mathrm{~Hz}, 1 \mathrm{H}), 7.29-7.22$ $(\mathrm{m}, 4 \mathrm{H}), 7.14(\mathrm{~d}, J=6.8 \mathrm{~Hz}, 1 \mathrm{H}), 7.06(\mathrm{~d}, J=8.4 \mathrm{~Hz}, 1 \mathrm{H})$, $5.36(\mathrm{~s}, 2 \mathrm{H}), 3.56(\mathrm{~s}, 3 \mathrm{H}) .{ }^{13} \mathrm{C} \mathrm{NMR}\left(151 \mathrm{MHz}, \mathrm{CDCl}_{3}\right)$ $\delta 161.89,151.55,139.61,137.85,135.13,134.98,130.30$, 129.13, 128.01, 126.60, 124.63, 123.30, 115.69, 114.09, 46.93, 28.73; APCI-HRMS $m / z$ calcd for $\mathrm{C}_{16} \mathrm{H}_{14} \mathrm{ClN}_{2} \mathrm{O}_{2}$ $\left(\mathrm{MH}^{+}\right), 301.0738$, found 301.0738. Purity (HPLC): $99.8 \%$.

\section{1-Benzyl-3-methyl-3,4-dihydroquinazolin-2(1H,3H)-dione}

(8b) The title compound was prepared in a yield of $11 \%$ : mp 155.2-156.1 ${ }^{\circ} \mathrm{C}$ (ethanol: petroleum ether). ${ }^{1} \mathrm{H}$ NMR $\left(600 \mathrm{MHz} \mathrm{CDCl}_{3}\right) \delta 8.25(\mathrm{dd}, J=7.9,1.6 \mathrm{~Hz}, 1 \mathrm{H}), 7.54$ (ddd, $J=8.7,7.3,1.6 \mathrm{~Hz}, 1 \mathrm{H}), 7.34(\mathrm{t}, J=7.4 \mathrm{~Hz}, 2 \mathrm{H})$, $7.26(\mathrm{dd}, J=7.6,3.3 \mathrm{~Hz}, 3 \mathrm{H}), 7.24-7.21(\mathrm{~m}, 1 \mathrm{H}), 7.12$ $(\mathrm{d}, J=8.4 \mathrm{~Hz}, 1 \mathrm{H}), 5.39(\mathrm{~s}, 2 \mathrm{H}), 3.56(\mathrm{~s}, 3 \mathrm{H}) .{ }^{13} \mathrm{C} \mathrm{NMR}$ $\left(151 \mathrm{MHz}, \mathrm{CDCl}_{3}\right) \delta 162.01,151.62,139.86,135.71$, 135.00, 128.99, 127.68, 126.46, 123.08, 115.65, 114.37, 47.40, 28.70; APCI-HRMS $m / z$ calcd for $\mathrm{C}_{16} \mathrm{H}_{15} \mathrm{~N}_{2} \mathrm{O}_{2}$ $\left(\mathrm{MH}^{+}\right), 267.1128$, found 267.1118. Purity (HPLC): $100 \%$.

\section{3-Methyl-1-phenethyl-3,4-dihydroquinazolin-2(1H,3H)-dione}

(8c) The title compound was prepared in a yield of $25 \%$ : mp 143.8-145.3 ${ }^{\circ} \mathrm{C}$ (petroleum ether: ethyl acetate). ${ }^{1} \mathrm{H}$ NMR $\left(600 \mathrm{MHz}, \mathrm{CDCl}_{3}\right) \delta 8.26(\mathrm{dd}, J=7.9,1.3 \mathrm{~Hz}, 1 \mathrm{H})$, 7.71-7.64 (m, 1H), 7.36-7.29 (m, 4H), 7.27-7.22 (m, 3H), 4.37-4.31 (m, 2H), 3.50 (s, 3H), 3.06-2.99 (m, 2H). ${ }^{13} \mathrm{C}$ NMR (151 MHz, $\left.\mathrm{CDCl}_{3}\right) \delta 161.96,150.90,139.55,137.74$, $135.08,129.24,128.82,128.81,126.91,122.90,115.63$, 113.32, 45.18, 33.61, 28.42; APCI-HRMS $m / z$ calcd for $\mathrm{C}_{17} \mathrm{H}_{17} \mathrm{~N}_{2} \mathrm{O}_{2}\left(\mathrm{MH}^{+}\right), 281.1284$, found 281.1262. Purity (HPLC): $99.6 \%$.

\section{3-Methyl-1-(2-phenoxyethyl)-3,4-dihydroquinazo-} lin-2(1H,3H)-dione (8d) The title compound was prepared in a yield of $10 \%$ : $\mathrm{mp} 148.8-165.3{ }^{\circ} \mathrm{C}$ (ethanol). ${ }^{1} \mathrm{H}$ NMR $\left(600 \mathrm{MHz} \mathrm{CDCl}_{3}\right) \delta 8.23(\mathrm{dd}, J=7.9,1.5 \mathrm{~Hz}, 1 \mathrm{H}), 7.70-$ $7.65(\mathrm{~m}, 1 \mathrm{H}), 7.52(\mathrm{~d}, J=8.5 \mathrm{~Hz}, 1 \mathrm{H}), 7.30-7.22(\mathrm{~m}, 3 \mathrm{H})$, $6.94(\mathrm{t}, J=7.3 \mathrm{~Hz}, 1 \mathrm{H}), 6.83(\mathrm{~d}, J=8.2 \mathrm{~Hz}, 2 \mathrm{H}), 4.55(\mathrm{t}$, $J=5.8 \mathrm{~Hz}, 2 \mathrm{H}), 4.34(\mathrm{t}, J=5.8 \mathrm{~Hz}, 2 \mathrm{H}), 3.49(\mathrm{~s}, 3 \mathrm{H}) .{ }^{13} \mathrm{C}$ NMR (151 MHz, $\left.\mathrm{CDCl}_{3}\right) \delta 161.95,158.14,151.25,140.32$,
$134.83,129.55,128.87,123.08,121.29,115.53,114.42$, 114.32, 65.19, 43.45, 28.43; APCI-HRMS $m / z$ calcd for $\mathrm{C}_{17} \mathrm{H}_{17} \mathrm{~N}_{2} \mathrm{O}_{3}\left(\mathrm{MH}^{+}\right), 297.1233$, found 297.1229. Purity (HPLC): $94.1 \%$.

4-((3-Methyl-2,4-dioxo-3,4-dihydroquinazolin-2(1H)-yl) methyl)benzonitrile (8e) The title compound was prepared in a yield of $30 \%$ : mp $194.5-281.9^{\circ} \mathrm{C}$ (petroleum ether: ethanol). ${ }^{1} \mathrm{H}$ NMR (600 MHz, DMSO) $\delta 8.09$ (dd, $J=7.8$, $1.1 \mathrm{~Hz}, 1 \mathrm{H}), 7.81(\mathrm{~d}, J=8.2 \mathrm{~Hz}, 2 \mathrm{H}), 7.68-7.62(\mathrm{~m}, 1 \mathrm{H})$, $7.52(\mathrm{~d}, J=8.2 \mathrm{~Hz}, 2 \mathrm{H}), 7.28(\mathrm{t}, J=7.5 \mathrm{~Hz}, 1 \mathrm{H}), 7.21$ $(\mathrm{d}, J=8.5 \mathrm{~Hz}, 1 \mathrm{H}), 5.47(\mathrm{~s}, 2 \mathrm{H}), 3.37$ (s, 3H). ${ }^{13} \mathrm{C} \mathrm{NMR}$ (151 MHz, DMSO) $\delta 161.80,151.49,142.78,139.82$, $135.63,133.03,128.49,127.98,123.46,119.20,115.72$, 115.12, 110.54, 46.65, 28.79; APCI-HRMS $m / z$ calcd for $\mathrm{C}_{17} \mathrm{H}_{14} \mathrm{~N}_{3} \mathrm{O}_{2}\left(\mathrm{MH}^{+}\right), 292.1080$, found 292.1059. Purity (HPLC): $97.0 \%$.

1 -(3-lodobenzyl)-3-methyl-3,4-dihydroquinazolin-2(1H,3H)-dione (8f) The title compound was prepared in a yield of $34 \%$ : mp $131.4-134.0{ }^{\circ} \mathrm{C}$ (ethyl acetate). ${ }^{1} \mathrm{H}$ NMR (600 MHz, DMSO) $\delta 8.08(\mathrm{dd}, J=7.8,1.5 \mathrm{~Hz}, 1 \mathrm{H})$, $7.76(\mathrm{~s}, 1 \mathrm{H}), 7.70-7.61(\mathrm{~m}, 2 \mathrm{H}), 7.33-7.24(\mathrm{~m}, 3 \mathrm{H}), 7.12$ $(\mathrm{t}, J=7.8 \mathrm{~Hz}, 1 \mathrm{H}), 5.35(\mathrm{~s}, 2 \mathrm{H}), 3.37(\mathrm{~s}, 3 \mathrm{H}) .{ }^{13} \mathrm{C} \mathrm{NMR}$ (151 MHz, DMSO) $\delta 161.80,151.49,139.91,139.55$, $136.54,135.60,135.55,131.25,128.42,126.34,123.38$, 115.68, 115.22, 95.67, 46.17, 28.80; APCI-HRMS $m / z$ calcd for $\mathrm{C}_{16} \mathrm{H}_{14} \mathrm{IN}_{2} \mathrm{O}_{2}\left(\mathrm{MH}^{+}\right), 393.0094$, found 393.0085. Purity (HPLC): $96.3 \%$.

\section{The determination of $\mathrm{IC}_{50}$ values for MAO inhibition}

The $\mathrm{IC}_{50}$ values were measured according to the literature procedure [28]. Recombinant human MAO-A and MAO-B were used as enzyme sources, and kynuramine served as enzyme-substrate. The enzyme reactions were carried out to a volume of $200 \mu \mathrm{L}$ in white polypropylene 96-well microtiter plates. The reactions consisted of substrate $(50 \mu \mathrm{M})$ and the test inhibitors $(0.003-100 \mu \mathrm{M})$ dissolved in potassium

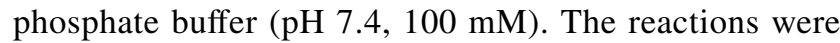
initiated with the addition of MAO-A $(0.0075 \mathrm{mg} / \mathrm{mL})$ or MAO-B $(0.015 \mathrm{mg} / \mathrm{mL})$ and were incubated for $20 \mathrm{~min}$ at $37{ }^{\circ} \mathrm{C}$. At endpoint, the reactions were terminated with the addition of $80 \mu \mathrm{L} \mathrm{NaOH}(2 \mathrm{~N})$ and the fluorescence was measured $\left(\lambda_{\mathrm{ex}}=310, \lambda_{\mathrm{em}}=400\right)$. Quantitative estimations of 4-hydroxyquinoline were made by constructing a linear calibration curve $(0.047-1.50 \mu \mathrm{M})$. From these data, the enzyme catalytic rates were calculated and the $\mathrm{IC}_{50}$ values were estimated by constructing sigmoidal plots of rate versus the logarithm of inhibitor concentration. For this purpose, the data were fitted to the one-site competition model incorporated into the Prism 5 software package. All $\mathrm{IC}_{50}$ 
values were measured in triplicate and are reported as the mean \pm standard deviation $(\mathrm{SD})$.

\section{Determination of reversibility of inhibition by dialysis}

Reversibility of inhibition was determined by dialysis. Dialysis was carried out with Slide-A-Lyzer dialysis cassettes with a molecular weight cut-off of 10,000 and a sample volume of $0.5-3 \mathrm{~mL}$. For this purpose, the literature procedure was followed [28]. MAO-A or MAO-B $(0.03 \mathrm{mg} /$ $\mathrm{mL}$ ) and the test inhibitors (at concentrations of $4 \times \mathrm{IC}_{50}$ ) were dissolved in potassium phosphate buffer $(100 \mathrm{mM}, \mathrm{pH}$ 7.4) containing 5\% sucrose and pre-incubated for $20 \mathrm{~min}$ at $37^{\circ} \mathrm{C}$. Stock solutions of the inhibitors were prepared in DMSO and added to yield a final concentration of $4 \%$ DMSO. The samples were subsequently dialysed for $24 \mathrm{~h}$ at $4{ }^{\circ} \mathrm{C}$ with the dialysis buffer (potassium phosphate buffer, $100 \mathrm{mM}, \mathrm{pH} 7.4$, containing $5 \%$ sucrose) being replaced with fresh buffer at $3 \mathrm{~h}$ and $7 \mathrm{~h}$ after dialysis was started. As positive controls, MAO-A and MAO-B were pre-incubated and dialysed in the presence of the irreversible inhibitors, pargyline $\left[\mathrm{IC}_{50}(\mathrm{MAO}-\mathrm{A})=13 \mu \mathrm{M}\right]$ and $(R)$-deprenyl $\left[\mathrm{IC}_{50}(\mathrm{MAO}-\mathrm{B})=0.079 \mu \mathrm{M}\right]$, respectively $[35,36]$. The concentrations of the irreversible inhibitors were $4 \times \mathrm{IC}_{50}$. Dialysis of the enzymes was also carried out in the absence of inhibitor and served as negative control. After $24 \mathrm{~h}$, the dialysis samples were diluted twofold with the addition kynuramine to yield an inhibitor concentration of $2 \times \mathrm{IC}_{50}$ and a kynuramine concentration of $50 \mu \mathrm{M}$. These reactions were incubated for $20 \mathrm{~min}$ at $37^{\circ} \mathrm{C}$, terminated with the addition of $\mathrm{NaOH}(2 \mathrm{~N})$, and the fluorescence of the samples was measured as described above. The residual enzyme activities were calculated and expressed as mean \pm SD of triplicate determinations. For comparison, undialysed mixtures of the test inhibitors and the MAOs were maintained at $4{ }^{\circ} \mathrm{C}$ for the same time period $(24 \mathrm{~h})$, and the residual enzyme catalytic rates were measured.

\section{Construction of Lineweaver-Burk plots}

The modes of MAO-A and MAO-B inhibition by $\mathbf{6 b}$ and 6c, respectively, were investigated by constructing sets of Lineweaver-Burk plots. For each inhibitor, plots were constructed in the absence of inhibitor and in the presence of five different inhibitor concentrations $\left({ }^{1}{ }_{4} \times \mathrm{IC}_{50}, 1 / 2 \times \mathrm{IC}_{50}\right.$, $\left.3 / 4 \times \mathrm{IC}_{50}, 1 \times \mathrm{IC}_{50}, 1 \frac{1}{4} \times \mathrm{IC}_{50}\right)$. The substrate, kynuramine, was used at concentrations ranging from $15-250 \mu \mathrm{M}$, while the final concentration of MAO-A and MAO-B was $0.015 \mathrm{mg}$ protein $/ \mathrm{mL}$. All enzyme reactions and catalytic activity measurements were carried out as described above for the $\mathrm{IC}_{50}$ determinations. Linear regression analysis was performed using the Prism version 5.0 software package.
The $\mathrm{K}_{\mathrm{i}}$ value was estimated from a replot of the slopes of the Lineweaver-Burke plots versus inhibitor concentration $\left(x\right.$-axis intercept equals $\left.-\mathrm{K}_{\mathrm{i}}\right)$.

\section{Electronic supplementary material}

${ }^{1} \mathrm{H}$ NMR, ${ }^{13} \mathrm{C}$ NMR, mass spectra and HPLC traces for the synthesised compounds.

Acknowledgements André Joubert and Johan Jordaan of the SASOL Centre for Chemistry, North-West University, recorded the NMR and MS spectra.

Funding This work was supported by grants from the National Research Foundation and the Medical Research Council of South Africa (Grant specific unique reference Numbers (UID) 85642, 96180, 916135). Opinions expressed and conclusions arrived at are those of the authors and therefore the NRF does not accept any liability in regard thereto.

\section{Compliance with ethical standards}

Conflict of interest The authors declare that they have no conflict of interest.

\section{References}

1. Youdim MB, Edmondson D, Tipton KF (2006) The therapeutic potential of monoamine oxidase inhibitors. Nat Rev Neurosci 7:295-309. https://doi.org/10.1038/nrn1883

2. Shih JC, Chen K, Ridd MJ (1999) Monoamine oxidase: from genes to behavior. Annu Rev Neurosci 22:197-217. https://doi. org/10.1146/annurev.neuro.22.1.197

3. Ramsay RR (2012) Monoamine oxidases: the biochemistry of the proteins as targets in medicinal chemistry and drug discovery. Curr Top Med Chem 12:2189-2209

4. Ramsay RR (2013) Inhibitor design for monoamine oxidases. Curr Pharm Des 19:2529-2539

5. Youdim MB, Bakhle YS (2006) Monoamine oxidase: isoforms and inhibitors in Parkinson's disease and depressive illness. $\mathrm{Br}$ J Pharmacol 147(Suppl 1):S287-S296. https://doi.org/10.1038/ sj.bjp. 0706464

6. Lum CT, Stahl SM (2012) Opportunities for reversible inhibitors of monoamine oxidase-A (RIMAs) in the treatment of depression. CNS Spectr 17:107-120

7. Birkmayer W, Knoll J, Riederer P, Youdim MB (1983) (-)-Deprenyl leads to prolongation of L-dopa efficacy in Parkinson's disease. Mod Probl Pharmacopsychiatr 19:170-176

8. Tipton KF (2018) 90 years of monoamine oxidase: some progress and some confusion. J Neural Transm (Vienna) 125:1519-1551. https://doi.org/10.1007/s00702-018-1881-5

9. deSouza RM, Schapira A (2017) Safinamide for the treatment of Parkinson's disease. Expert Opin Pharmacother 18:937-943. https ://doi.org/10.1080/14656566.2017.1329819

10. Da Prada M, Zurcher G, Wuthrich I, Haefely WE (1988) On tyramine, food, beverages and the reversible MAO inhibitor moclobemide. J Neural Transm Suppl 26:31-56 
11. Flockhart DA (2012) Dietary restrictions and drug interactions with monoamine oxidase inhibitors: an update. J Clin Psychiatr 73(Suppl 1):17-24. https://doi.org/10.4088/JCP.11096su1c.03

12. Gillman PK (2018) A reassessment of the safety profile of monoamine oxidase inhibitors: elucidating tired old tyramine myths. J Neural Transm (Vienna) 125:1707-1717. https://doi.org/10.1007/ s00702-018-1932-y

13. Bieck PR, Antonin KH (1989) Tyramine potentiation during treatment with MAO inhibitors: brofaromine and moclobemide vs irreversible inhibitors. J Neural Transm Suppl 28:21-31

14. Bieck PR, Firkusny L, Schick C, Antonin KH, Nilsson E, Schulz R, Schwenk M, Wollmann H (1989) Monoamine oxidase inhibition by phenelzine and brofaromine in healthy volunteers. Clin Pharmacol Ther 45:260-269

15. Carradori S, Secci D, Petzer JP (2018) MAO inhibitors and their wider applications: a patent review. Expert Opin Ther Pat 28:211226. https://doi.org/10.1080/13543776.2018.1427735

16. Chen K, Wang K, Kirichian AM, Al Aowad AF, Iyer LK, Adelstein SJ, Kassis AI (2006) In silico design, synthesis, and biological evaluation of radioiodinated quinazolinone derivatives for alkaline phosphatase-mediated cancer diagnosis and therapy. Mol Cancer Ther 5:3001-3013. https://doi.org/10.1158/1535-7163. MCT-06-0465

17. Mhaske SB, Argade NP (2006) The chemistry of recently isolated naturally occurring quinazolinone alkaloids. Tetrahedron 62:9787-9826. https://doi.org/10.1016/j.tet.2006.07.098

18. Kshirsagar UA (2015) Recent developments in the chemistry of quinazolinone alkaloids. Org Biomol Chem 13:9336-9352. https ://doi.org/10.1039/c5ob01379h

19. Jafari E, Khajouei MR, Hassanzadeh F, Hakimelahi GH, Khodarahmi GA (2016) Quinazolinone and quinazoline derivatives: recent structures with potent antimicrobial and cytotoxic activities. Res Pharm Sci 11:1-14

20. Gokhan-Kelekci N, Koyunoglu S, Yabanoglu S, Yelekci K, Ozgen O, Ucar G, Erol K, Kendi E, Yesilada A (2009) New pyrazoline bearing $4(3 \mathrm{H})$-quinazolinone inhibitors of monoamine oxidase: synthesis, biological evaluation, and structural determinants of MAO-A and MAO-B selectivity. Bioorg Med Chem 17:675-689. https://doi.org/10.1016/j.bmc.2008.11.068

21. Khattab SN, Abdel Moneim SA, Bekhit AA, El Massry AM, Hassan SY, El-Faham A, Ali Ahmed HE, Amer A (2015) Exploring new selective 3-benzylquinoxaline-based MAO-A inhibitors: design, synthesis, biological evaluation and docking studies. Eur J Med Chem 93:308-320. https://doi.org/10.1016/j.ejmec h.2015.02.020

22. Khattab SN, Haiba NS, Asal AM, Bekhit AA, Amer A, AbdelRahman HM, El-Faham A (2015) Synthesis and evaluation of quinazoline amino acid derivatives as mono amine oxidase (MAO) inhibitors. Bioorg Med Chem 23:3574-3585. https://doi. org/10.1016/j.bmc.2015.04.021

23. Qhobosheane MA, Legoabe LJ, Petzer A, Petzer JP (2018) The monoamine oxidase inhibition properties of C6-mono- and N3/ C6-disubstituted derivatives of $4(3 \mathrm{H})$-quinazolinone. Bioorg Chem 85:60-65. https://doi.org/10.1016/j.bioorg.2018.12.030
24. Qhobosheane MA, Petzer A, Petzer JP, Legoabe LJ (2018) Synthesis and evaluation of 2 -substituted $4(3 \mathrm{H})$-quinazolinone thioether derivatives as monoamine oxidase inhibitors. Bioorg Med Chem 26:5531-5537. https://doi.org/10.1016/j.bmc.2018.09.032

25. Khan I, Zaib S, Batool S, Abbas N, Ashraf Z, Iqbal J, Saeed A (2016) Quinazolines and quinazolinones as ubiquitous structural fragments in medicinal chemistry: an update on the development of synthetic methods and pharmacological diversification. Bioorg Med Chem 24:2361-2381. https://doi.org/10.1016/j. bmc.2016.03.031

26. Meiring L, Petzer JP, Petzer A (2013) Inhibition of monoamine oxidase by 3,4-dihydro-2 $(1 \mathrm{H})$-quinolinone derivatives. Bioorg Med Chem Lett 23:5498-5502. https://doi.org/10.1016/j. bmcl.2013.08.071

27. Meiring L, Petzer JP, Petzer A (2017) C6- and C7-Substituted 3,4-dihydro-2 $(1 \mathrm{H})$-quinolinones as inhibitors of monoamine oxidase. Drug Res (Stuttg) 67:170-178. https://doi. org/10.1055/s-0042-120116

28. Mostert S, Petzer A, Petzer JP (2015) Indanones as high-potency reversible inhibitors of monoamine oxidase. ChemMedChem 10:862-873. https://doi.org/10.1002/cmdc.201500059

29. Novaroli L, Reist M, Favre E, Carotti A, Catto M, Carrupt PA (2005) Human recombinant monoamine oxidase B as reliable and efficient enzyme source for inhibitor screening. Bioorg Med Chem 13:6212-6217. https://doi.org/10.1016/j.bmc.2005.06.043

30. Silva EMP, Melo T, Sousa BC, Resende D, Magalhaes LM, Segundo MA, Silva AMS, Domingues MRM (2016) Do cinnamylideneacetophenones have antioxidant properties and a protective effect toward the oxidation of phosphatidylcholines? Eur J Med Chem 121:331-337. https://doi.org/10.1016/j.ejmech.2016.05.040

31. Yacoubian TA, Standaert DG (2009) Targets for neuroprotection in Parkinson's disease. Biochim Biophys Acta 1792:676-687. https://doi.org/10.1016/j.bbadis.2008.09.009

32. Fowler JS, Volkow ND, Logan J, Wang GJ, MacGregor RR, Schyler D, Wolf AP, Pappas N, Alexoff D, Shea C et al (1994) Slow recovery of human brain MAO B after L-deprenyl (Selegeline) withdrawal. Synapse 18:86-93. https://doi.org/10.1002/syn.89018 0203

33. Fowler JS, Logan J, Shumay E, Alia-Klein N, Wang GJ, Volkow ND (2015) Monoamine oxidase: radiotracer chemistry and human studies. J Labelled Comp Radiopharm 58:51-64. https://doi. org/10.1002/jlcr.3247

34. Petzer A, Pienaar A, Petzer JP (2013) The inhibition of monoamine oxidase by esomeprazole. Drug Res (Stuttg) 63:462-467. https ://doi.org/10.1055/s-0033-1345163

35. Strydom B, Bergh JJ, Petzer JP (2012) The inhibition of monoamine oxidase by 8-(2-phenoxyethoxy)caffeine analogues. Arzneimittelforschung 62:513-518. https://doi.org/10.1055/s-0032-13236 62

36. Petzer A, Harvey BH, Wegener G, Petzer JP (2012) Azure B, a metabolite of methylene blue, is a high-potency, reversible inhibitor of monoamine oxidase. Toxicol Appl Pharmacol 258:403-409. https://doi.org/10.1016/j.taap.2011.12.005

\section{Affiliations}

\section{Lereze Marais $^{1} \mathbb{D} \cdot$ Anél Petzer $^{1,2} \cdot$ Jacobus P. Petzer ${ }^{1,2} \cdot$ Lesetja J. Legoabe $^{1}$}

1 Centre of Excellence for Pharmaceutical Sciences, NorthWest University, Private Bag X6001, Potchefstroom 2520, South Africa
2 Pharmaceutical Chemistry, School of Pharmacy, North-West University, Private Bag X6001, Potchefstroom 2520, South Africa 